\title{
Hermēneis in the documentary record from Hellenistic and Roman Egypt: interpreters, translators and mediators in a bilingual society
}

Article

Published Version

Mairs, R. (2020) Hermēneis in the documentary record from Hellenistic and Roman Egypt: interpreters, translators and mediators in a bilingual society. Journal of Ancient History, 8 (1). pp. 50-102. ISSN 2324-8114 doi:

https://doi.org/10.1515/jah-2019-0001 Available at https://centaur.reading.ac.uk/83325/

It is advisable to refer to the publisher's version if you intend to cite from the work. See Guidance on citing.

To link to this article DOI: http://dx.doi.org/10.1515/jah-2019-0001

Publisher: De Gruyter

All outputs in CentAUR are protected by Intellectual Property Rights law, including copyright law. Copyright and IPR is retained by the creators or other copyright holders. Terms and conditions for use of this material are defined in the End User Agreement. 


\section{CentAUR}

Central Archive at the University of Reading

Reading's research outputs online 
Rachel Mairs*

\section{Hermēneis in the Documentary Record from Hellenistic and Roman Egypt: interpreters, translators and mediators in a bilingual society}

https://doi.org/10.1515/jah-2019-0001

Abstract: Egypt of the Hellenistic and Roman periods remains the most thoroughly documented multilingual society in the ancient world, because of the wealth of texts preserved on papyrus in Egyptian, Greek, Latin and other languages. This makes the scarcity of interpreters in the papyrological record all the more curious. This study reviews all instances in the papyri of individuals referred to as hermèneus in Greek, or references to the process of translation/interpreting. It discusses the terminological ambiguity of hermèneus, which can also mean a commercial mediator; the position of language mediators in legal cases in Egyptian, Greek and Latin; the role of gender in language mediation; and concludes with a survey of interpreting in Egyptian monastic communities in Late Antiquity.

Keywords: Hellenistic Egypt, Roman Egypt, translation, interpreting, multilingualism papyri, inscriptions

\section{Introduction}

Graeco-Roman Egypt, as a profoundly bilingual society with multiple written as well as spoken languages (whatever individual rates and degrees of bilingual competence), might be expected to yield extensive evidence of mediation between languages, especially between Egyptian and Greek. Language mediation and mediators, especially oral interpreters, are remarkably poorly attested in the Graeco-Roman world as a whole. Only a handful of Latin inscriptions and documentary texts mention interpreters (interpretes) in the European provinces of the

*Corresponding author: Rachel Mairs, Department of Classics, University of Reading, Reading RG6 6AA, United Kingdom, E-Mail: r.mairs@reading.ac.uk 
Roman empire. ${ }^{1}$ In contrast, over one hundred Greek papyri, ostraca and inscriptions from Egypt contain mention of interpreters (hermeneis). ${ }^{2}$ This work aims to discuss and contextualise each of these examples, providing an analysis both of the semantic range of the Greek term hermèneus and of the professional range of those so defined.

In papyrological terms, one hundred is a relatively small number of documents, so it is fair to say - as many have - that interpreters and interpreting activities are in fact poorly attested in the Egyptian documentary record. ${ }^{3}$ Given the extensive evidence for language contact in Hellenistic and Roman Egypt, this absence is indeed curious. The main reasons for the silence of the sources are, as again many have already argued, solidly practical ones. ${ }^{4}$ Many people in Egypt will have been bilingual to some degree, and capable of interacting with speakers of other languages without an interpreter. Those who did not have sufficient command of a language for a particular situation will have been able to draw, informally, on the language skills of others who were bilingual. In such a scenario, bilingualism and interpreting were so unremarkable and unproblematic that they required little comment. Where language mediation is mentioned, it is generally because it is either exceptional, or presented some special difficulty. There is also the problem that the circumstances in which oral linguistic behaviour finds reflection in the written record are very restricted. There are, however, notable exceptions, and in the following discussion we will encounter a number of cases (most importantly memoranda of oral legal hearings) where a written account of a conversation conducted through an interpreter is preserved.

As well as those individuals who played the role of oral interpreter between languages, the material from Egypt also yields a large number of references to written translation and its practitioners, and to individuals who, while designated as hermēneis, fulfilled roles which were not primarily linguistic. ${ }^{5}$ In modern scholarly analysis we frequently judge "interpreters" according to different criteria

1 See Mairs (2012b); Mairs (forthcoming).

2 See, briefly, Mairs (2012a).

3 P. Col. Zen. II 63, note to 1. 7; Peremans (1983b), 11; Hanson (1991), 176; Bagnall (1993), 233, “a good example of the reticence of the documents;” Rowlandson (2004), 166; Bagnall, Helms and Verhoogt (2005), 27; contra: Rochette (1995b), 62, on the supposed "frequency" of $\delta$ '’ $\dot{\rho} \mu \eta \nu \varepsilon \dot{\varepsilon} \omega \varsigma$ in the papyri.

4 See e.g. Rowlandson (2004), 159.

5 The papyri, as ever, also throw up a couple of apparently random and rather strange outliers. In one case ( $P$. Achm. 7) it is possible that Hermēneus is a personal name (see below). Hermēneia also appears once as a priestly office, in a sale of such offices which includes a joint propheteia, baiphoria ("palm-bearing") and hermēneia for Souchos, Ammon, Hermes, Hera and related gods (P. Lund

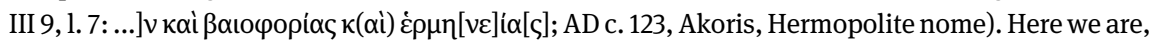


than many of our ancient sources, where the same terms are frequently used to refer to oral interpreting as to written translation, and to forms of non-linguistic mediation. Neither hermēneis nor interpres means exclusively "interpreter," just as the English "interpret" has a range of related meanings. In the Egyptian evidence there are a number of cases in which an individual described in a document as a hermèneus is not demonstrably engaged in any form of linguistic mediation, and where his position is in fact closer to that of a broker or middleman in a commercial transaction. It is probable that these broker-hermeneis used both the Greek and the Egyptian languages in the course of their job, but it is also clear that any linguistic aspect to their professional remit has been subsumed into a broader role as a commercial mediator. Semantically and functionally, the connection between both species of hermeneus is straightforward. The common action of the hermēneus is that he mediates between languages and/or parties in a transaction, and in a multilingual society acting as a middleman must often have involved dealing with speakers of different languages. The many hermēneis who were involved in trade and diplomacy are seldom "pure" interpreters, but play a much more active role in their respective careers. It is their position and status in these careers which makes their role as interpreters even worth recording in a document. The existence of hermeneis whose professional function is not solely or principally linguistic need not compromise the fact that other examples in the papyrological record are demonstrably interpreters in the linguistic sense. What it does mean is that each case must be assessed carefully on its own merits, and in the absence of clear evidence one way or the other - rigid categorisation must be resisted.

There have been a number of previous studies of the evidence for interpreters and the meaning of the term hermèneus in the papyri, ${ }^{6}$ but none are really either satisfactory or comprehensive. The most useful critical treatment of the material from the Roman period is the concise but reasoned discussion by Bagnall. ${ }^{7}$ Most previous studies have struggled to reconcile the connected but different meanings of hermèneus, as interpreter or simply as mediator, and have too often attempted to make definitive statements about the activities of an individual hermèneus which are not really supported by the evidence. The typology of Egyptian hermēneis drawn up by Wiotte-Franz, ${ }^{8}$ for example, is neat, and her attributions of in-

of course, dealing with "interpretation" in the religious sense of interpreting dreams or oracles. (See the Appendix on "interpretation" in Christian hagiography.)

6 Taubenschlag (1951); Calderini (1953); Peremans (1983b); Rochette (1994); Rochette (1995b); Wiotte-Franz (2001), 63-71, 111-118; Mairs (2012a).

7 Bagnall (1993), 233-235.

8 Wiotte-Franz (2001), 117-118. 
dividual hermèneis to a particular category are often cautiously argued, but it does not give an accurate impression of the actual state of the evidence. We cannot reasonably categorise the hermèneis from Egypt in this way at all.

I have aimed to be comprehensive in my coverage of occurrences of hermeneis, hermèneuein and hermēneia in the documentary evidence from Egypt, and trust that I have been reasonably successful in this, but one of the great pleasures of working with papyri is that there will inevitably be new discoveries and publications, and that these will most probably come sooner rather than later. A weakness in my discussion, of which I am painfully aware, is that I have been unable to find any reference in Demotic documentary sources to interpreters and interpreting. Although there are Greek translations of Demotic documents, and in some cases the originals are preserved, the actual references to translation appear, of course, in the Greek translation rather than the Demotic original (see further below). Some material from Demotic and Coptic, and the problems of the Egyptian terminology for interpreting, will be discussed in the Appendix. A possible reason for the one-sided nature of our evidence (beyond that caused simply by the differential publication rate of Greek versus Demotic papyri) is that, in official contexts which generated a paper trail, it will generally have been Egyptian speakers who needed to use a Greek interpreter, or Greek speakers who needed to use a Latin interpreter, rather than vice versa. But I am also quite sure that a more in-depth study of interpreting, and language contact in general, in the Demotic sources would yield much more useful material.

A few brief comments are in order as to what I do and do not consider to fall within the remit of this study. Although I do not discuss literary translation - a topic which has been ably covered by others ${ }^{9}$ - the translation of documentary texts in Hellenistic and Roman Egypt demands to be considered alongside the evidence for oral interpreting, and the diverse para-interpreting activites of individuals described as hermenneis. In part, this is because the same terminology is employed for all these activities, and also because there are cases in which it is not entirely certain whether a particular individual is an oral interpreter or written translator, or something else entirely. In addition, the treatment of translation and translators in the documentary record has much in common with the treatment of interpreters and interpreting - in Egypt and elsewhere. Both translators and interpreters, for example, are rarely named. There are instances in which either translation or interpreting are expressly mentioned as having taken place, in order to clarify the legal position of a document or testimony.

9 Kytzler (1989); Rochette (1995a); Wiotte-Franz (2001) and especially McElduff (2013). 
Although the question of multilingualism in Hellenistic and Roman Egypt - a subject for which there is an almost unmanageable amount of papyrological evidence and in which there has been considerable recent scholarly interest - bears on that of interpreting and translation, I consider this to be the background which informs my discussion, rather than its major theme, and refer interested readers elsewhere. ${ }^{10}$ Societal multilingualism created communication problems, which were solved through individual multilingualism, by interpreting and by translation. But there is a danger of straying into a general, and inevitably very lengthy, discussion of multilingualism in Egypt, and I have resisted this as far as possible.

I begin with a survey of written translation in Egyptian documents of the Hellenistic and Roman periods: the contexts in which translation was necessary; the terms in which it is described; and official constraints on language use. Next, I discuss the small concentration of hermeneis from an individual archive, that of Zenon, which helps us to establish that, even as early as the third century BC, hermēneis might play a primarily commercial role. A brief digression is made into a group of documents from the early Roman period which measure commodities by a "measure of the hermèneus." These are not named individuals, but they appear to be village officials who acted as regulators of weights and measures. The majority of the hermēneis from the documentary record are considered in the following section, where I attempt to assess, in each case, the relative probability of him having played a primarily linguistic or primarily commercial role. In most cases, it is very difficult to decide. Some resist classification entirely. Interpreters in law courts are, unfortunately, mostly anonymous, but mentions of them provide a valuable record of oral linguistic behaviour. The same is true of the small number of references to written material in Greek being translated aloud for Egyptian speakers, a scenario which we must nevertheless consider to have been very common. Finally, I append a few thematic discussions which draw on various of the documents already discussed: chronological development and geographical variation (or lack thereof) in the meaning of hermèneus; the question of a gendered aspect to bilingualism and interpreting for women; the ethnicity and languages spoken by interpreters and their clients - a subject on which we can unforunately say very little; interpreters' pay; and interpreting in early Egyptian monastic communities (Appendix).

10 Latin and Greek: Adams (2003), 527-642; Greek and Egyptian: Fewster (2002); literature review: Dickey (2003); a diachronic survey: Papaconstantinou (2010). 


\section{Translation in documentary texts ${ }^{11}$}

Language contact in Hellenistic and Roman Egypt was a matter of contact between several literate, as well as oral, traditions. ${ }^{12}$ This required the most careful management in the period in which Demotic Egyptian was still being used extensively alongside Greek, along with two separate legal systems. ${ }^{13}$ In 146 BC, Ptolemy VI Philometor issued an order that Demotic legal documents should be docketed in Greek and registered in the official archives, from which point short registration statements in Greek begin to be appended to Demotic documents. ${ }^{14} \mathrm{~A}$ decree of $118 \mathrm{BC}$ further clarifies the relationship between the two legal systems: regardless of the ethnic background of the parties involved (and by the late second century this might not be a straightforward question), the language of the original contract is henceforth to decide whether any case is taken before the Egyptian courts or the Greek courts. ${ }^{15}$ Supporting documentation might also have to be translated into Greek in order to be used in a Greek court case. We therefore have, from the Hellenistic period, a certain number of documents which declare themselves to be Greek translations of Demotic originals. In a few cases, the Demotic is also preserved. While we can look at translation methodology and the formulae used to record that a translation has taken place, the translators are, with one early exception, anonymous.

In Demotic-Greek translations in particular, but also in translations between Latin and Greek, there is a striking terminological consistency. The statement that

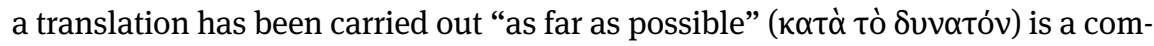
mon caveat. Our last evidence for the translation of documentary texts between

11 The following will not be concerned with texts on stone, such as the royal decrees of the Ptolemies, which contained translated text in two or more languages. Although these are translations, and may contain a clause mentioning that they are to be set up in different scripts, they contain no explicit reference to the translation process itself (e.g. Canopus Decree, 11. 73-75: $\alpha \dot{v} \alpha \gamma \rho \alpha \psi \alpha \dot{\alpha} \tau \omega \sigma \alpha \nu$

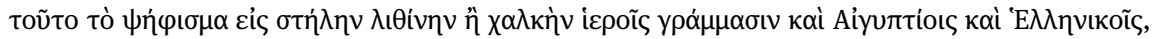
Pfeiffer 2004). Peremans (1985) surveys a representative selection of non-literary translations from Hellenistic period Egypt. My focus is rather on translation in the papyrological record, and principally on texts commissioned and used by private individuals in their dealings with the legal systems of Hellenistic and Roman Egypt. (A foray into epigraphic territory will, however, be made in the case of the inscription bearing a translation of a letter of Diocletian discussed below)

12 For an overview of translation between Demotic and Greek, and Latin and Greek, see Rochette (1994).

13 Egyptian, the language with the longest recorded written tradition, passes through a curious phase between around the second and fourth centuries AD in which it had no written form in common use: Lewis (1993).

14 P. Par. 65; Pestman (1985b).

15 P. Tebt. I 5, 11. 207-220; on this interpretation, see Pestman (1985a). 
Demotic and Greek falls in the early first century AD. From the mid second century $\mathrm{AD}$, we have a small but significant corpus of material dealing with translation between Latin and Greek, again primarily in legal contexts. Under Roman law, certain documents, such as wills, had to be written in Latin. There are a few bilingual papyri containing the Latin text alongside Greek translations made at the same time, for the use of the parties involved. Knowledge of Latin was not particularly widespread in Roman Egypt. ${ }^{16}$ Other documents contain quotations from Latin papers, and the fact that they are translations is signposted. In a couple of cases, the name of the translator is preserved, but, as in earlier translations between Demotic and Greek, the vast majority of translators remain frustratingly elusive.

Greek and Demotic. There are a few cases in which reference is made to Greek translations of Demotic originals, without the documents themselves being preserved. UPZ II 218, a sale, refers to a document "in native letters, which was trans-

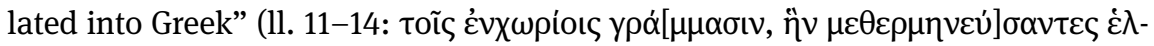
$\lambda$ nvıбí, 131-130 BC, Thebes). Also from Thebes, from the archive of the Theban choachytes which supplies two of the most interesting preserved translations (see below), come two records of legal proceedings in which Egyptian documents were brought as evidence. In the first, it is not specified whether these papers have been translated in order to be brought before the court, although we should prob-

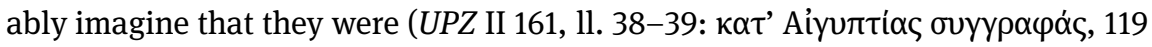
$\mathrm{BC}$, Thebes). The other text is more explicit: here we are told that one of the parties provided “copies of Egyptian contracts, translated into Greek" in support of his

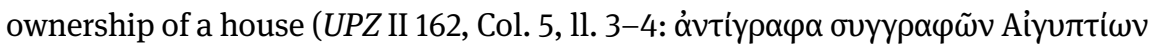

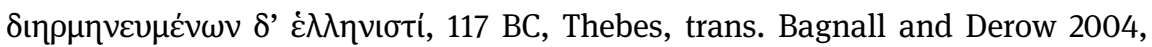
No. 132).

The earliest example of a text which states explicitly that it was the work of a translator is a witness testimony in a case before the stratēgos from Herakleopolis (P. Heid. VIII 416, first half of the second century BC). At the end of the document, in a second hand, is the caption "Theon son of Theon, Persian of the epigone,

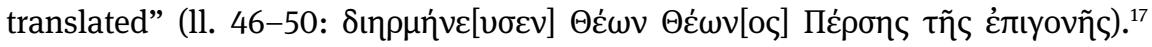
The name of the witness is Herieus, an Egyptian name, so we should suppose that it is his oral Egyptian testimony which has been rendered into written Greek. Whether Theon himself wrote, or dictated to another, is not clear, and we do not

16 Adams (2003), 527-528.

17 On "Persians of the epigonē," see Clarysse (1994); Vandorpe (2008). 
know whether he held any official position, or was co-opted temporarily to serve as interpreter.

From the mid second century BC, we begin to find Greek translations of Demotic legal documents, for use in cases before a Greek law court. The reasons for the production of such translations, and their emergence at this period, have been discussed above. What is striking - although perhaps, given the legal context, unsurprising - is the degree of terminological consistency in how these translations refer to themselves. The standard phraseology, which appears at the very beginning of each document, is "Copy of an Egyptian document, translated into

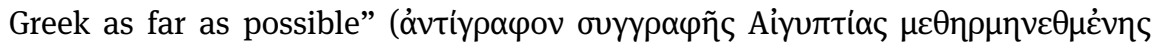

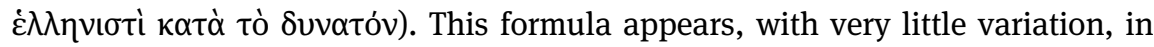
thirteen preserved texts, dating between 146 BC and AD $11 .{ }^{18}$ The original Demotic of seven of these documents is preserved, relating to two separate legal proceedings. One involved the community of the Theban choachytes in the latter part of the third century BC. ${ }^{19}$ The other concerned the priest Satabous of Soknopaiou Nesos in the early Roman period. ${ }^{20}$

I have discussed these texts and the translation methodology employed in them at greater length elsewhere. ${ }^{21}$ The points which bear reiterating are that:

1. These are relatively literal translations, preserving the phraseology of the Demotic original, not recasting it in the form of a Greek legal document. There is a certain amount of evidence of linguistic interference from Demotic, ${ }^{22}$ but this may have as much to do with the fact that these texts are translations, as with their authors' competence in Greek.

2. The Greek is not of a high literary standard, but it is perfectly functional. The caveat kata to dunaton "as far as possible" is not a modest admission of imperfection or an apology for poor translation, ${ }^{23}$ but a piece of legalese designed to note that a translation has taken place, at the same time as absol-

18 UPZ II 175, 146 BC, Thebes; UPZ II 177, 136 BC, Thebes; P. Giss. I 36, 134 BC, Pathyris; P. Tebt. I 164, 112 BC, Kerkeosiris; BGU III 1002, 55 BC, Hermopolis Magna; PSI V 549, 41 BC, Oxyrhynchus; BGUXVI 2594, 8 BC, Chennis; CPR XV 1, 3 BC, Soknopaiou Nesos; CPR XV 2, CPR XV 3, CPR XV 4, SB I 5231, SB I 5275, all AD 11, Soknopaiou Nesos.

19 UPZ II 175 = P. Berl. dem. 3119 and UPZ II 177 = P. Berl. dem. 5507; see Mairs and Martin (2008/ 2009); Mairs (2018).

20 The variant translations $C P R$ XV 2, $C P R$ XV 3, $C P R$ XV 4, SB I 5231, $S B$ I $5275=P . B M$ 262; $C P R$ XV 1 belongs to the same dossier, but the Demotic original is not preserved; see Schentuleit (2001) and (2007).

21 Mairs (2018).

22 See e.g. Mussies (1968), on P. Giss. I 36 and BGU III 1002.

23 Pace Rochette (1994), 319. 
ving all concerned of responsibility for any inaccuracies. A freer translation of the clause might be "in good faith." Caveat lector.

3. The translators worked selectively, translating only those pieces of information which were necessary in a case before a Greek court. Sometimes this meant abbreviating the lengthy Demotic legal clauses. The actual documents selected to be translated were, again, only those necessary under Greek law: in the two sets of papers from the archive of the Theban choachytes, the Demotic sale document was translated but not the accompanying cession document, which was needed only in Egyptian law.

4. The translator is in each case anonymous.

This last point has been a source of some frustration in studies of translation between Demotic and Greek. In the Roman period, as will be seen in the following section, we do know the names of some of our translators between Latin and Greek - not that this, in the end, helps us to discover much about their ethnic background or social position. Peremans conveniently summarises earlier opinions on the identity of Demotic-Greek translators of documentary texts. ${ }^{24}$ Wilcken was of the opinion that the monographos was responsible for producing translations for Greek tribunals. ${ }^{25}$ But it is equally possible that such translations were privately commissioned and paid for, by the individuals bringing the law suit. As noted above, these translators were competent, and had at least enough specialised legal knowledge to know when and how to abridge a Demotic legal document to retain its sense and validity in Greek. Even if they were working privately, they therefore had some current or former connection with the legal profession. The question of the legal knowledge of translators between Demotic and Greek is of particular pertinence, because we do have some confirmation from later translations between Latin and Greek that professional legal personnel were involved (see further below). The important difference is that, in the cases where a Roman legal expert is mentioned as a translator, it is in a document which itself contains data in both Latin and Greek: the translation was produced at the same time as the original. The Demotic-Greek translations, in contrast, were in some cases produced many years after the original (around ten years between P. Berl. dem. 3119, the Demotic original of UPZ II 175, and its use in a Greek lawsuit), and probably not by the same personnel.

24 Peremans (1983), 267 and (1985), 259.

25 Commentary to UPZ I, p. 602. 
Greek and Latin. For the most part, no attempt appears to have been made to replace the Greek bureaucracy of Egypt with a Latin one. The surviving documents which mention or contain translation between Latin and Greek are therefore limited to those circumstances where the use of Latin was unavoidable, or officially prescribed. Decrees from the emperor, for example, might be translated into Greek for circulation and public display, although direct epigraphic references to such translations are surprisingly few. A communication of Diocletian to the people of Elephantine and Philae, for example, recorded by an eighteenthcentury traveller on the wall of a temple at Elephantine, but no longer extant, contains a direct quotation of a letter from the emperor under the heading $\tau \tilde{\omega} v$

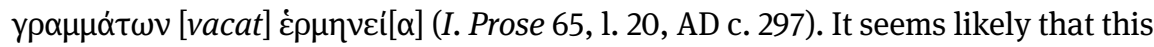
translation is of a letter referred to in the first part of the inscription, regarding benefices and taxation; the first part of the inscription may itself be a translation from the Latin, but this is not explicitly stated. ${ }^{26}$ From a much later period comes a rare, apparently unique, mention of translation into Egyptian, a decree of the Dux of the Thebaid which stipulates that it should be "translated into the native dia-

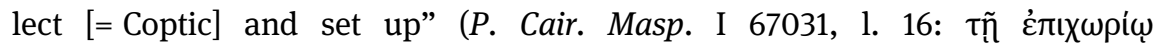

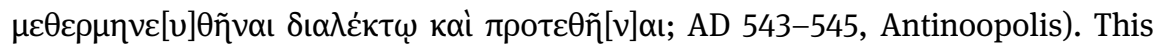
text bears comparison with much earlier Ptolemaic trilingual decrees on stone, which contain a similar prescription without explicit mention of a translation process. $^{27}$

Most of our translated documentation, however, was generated because certain Roman legal documents, such as wills, had to be made in Latin. In Egypt, where the vast majority of the population were not Latin speakers, translating such documents into Greek was necessary both for personal record and future reference, and for subsequent use and quotation in later legal disputes transacted in Greek. It might be necessary, for example, for a Greek document concerning inheritance to cite a Latin will in translation, ${ }^{28}$ or mention that such a document was opened and translated. ${ }^{29}$ Other types of Latin document which might be cited included release from patria potestas, ${ }^{30}$ or possessio bonorum. ${ }^{31}$ As in DemoticGreek translations, kata to dunaton and associated phrasings make an appear-

26 Brennan (1989), 197-198.

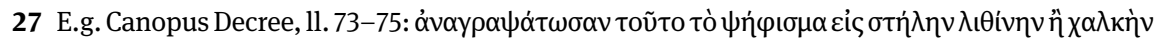

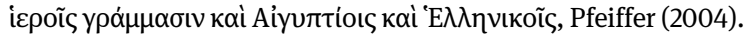

28 PSI XIII 1325, AD 176-180, Herakleopolis; BGU VII 1662, AD 182, Ptolemais Euergetis.

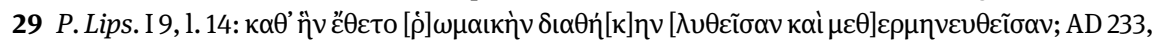
Hermopolis Magna.

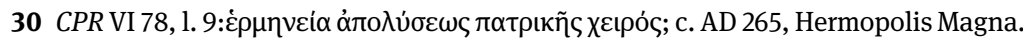

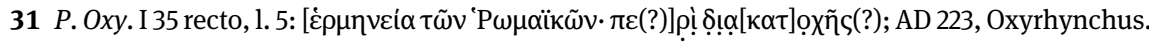


ance in such citations. ${ }^{32}$ The latter example, a ruling on the legal rights of minors in which a chapter from the lex Laetoria is translated, is of especial interest, because the text of this law has not been preserved elsewhere. Unfortunately, the papyrus breaks after the introductory clause to the translation, and the law itself is lost.

As in the Hellenistic period, some documents mention translations which are not themselves preserved. In support of her claim to an inheritance, one Aurelia Thermouthion submits two copies of "a copy, translated into Greek letters as far as possible, of the (claim to a) deed of succession" (P. Oxy. XIX 2231, 11. 26-28:

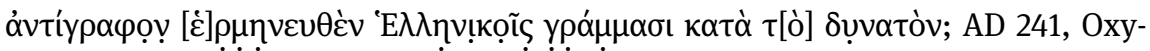
rhynchus). ${ }^{33} \mathrm{~A}$ slightly cryptic reference in a set of military accounts from late third-century Oxyrhynchus may refer to the problems encountered by those who had to deal with documentation in different languages. One of the items reads: "to the one registered in the Roman receipt whose name was not found to have been

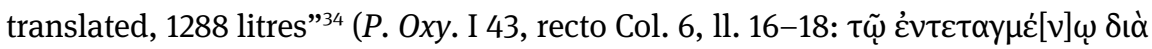

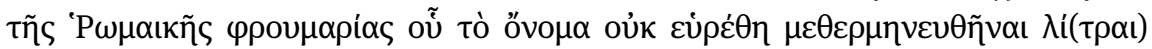
Aблп; AD 295, Oxyrhynchus). Are these the words of a secretary at a loss as to how to translate a Roman technical term, or frustrated at the omission of an important name in an already-existing translation?

Latin-Greek translations are of three main types: independent documents preserving a Greek translation of a Latin original; bilingual documents in which the Latin text is repeated, usually not verbatim, in Greek; and short translated excerpts or citations within a longer text. It is difficult to say whether independent translations or translated quotations were made at the same time as the original document or later, as needed for personal or official purposes. With the bilingual documents, both texts were produced at the same time. The situation was evidently different than that under which most Greek translations of Demotic legal papers were produced. These Demotic papers were commissioned by people who used them to operate within the Egyptian legal system, in a language which they had chosen to use. Only if a subsequent case in which these documents were

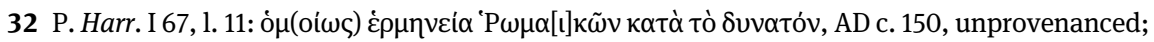

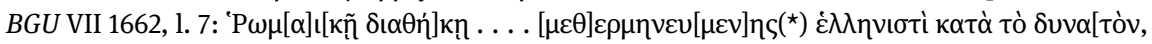

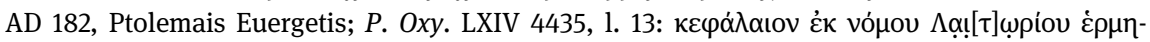

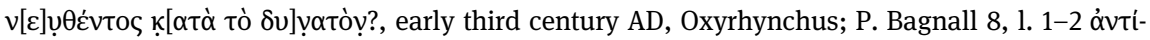

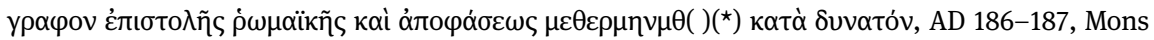
Claudianus.

33 Another, fragmentary, text from Oxyrhynchus also seems to mention a translation in a legal

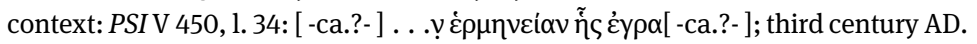

34 I am grateful to the anonymous reviewer for their comments on this passage, and follow their suggested translation. 
relevant was taken before a Greek court was a translation necessary, and this might be some years later. Our Roman period translations, in contrast, are of texts originally written in Latin because this was compulsory. A Roman will, for example, had to be written in Latin for it to have legal force. The Greek translations of such texts were needed so that the parties involved could actually use and consult them, if they did not know Latin, as most people in Egypt at this period did not. There is therefore a strong case to be made that such translations were generally commissioned at around the same time as the originals.

The type of documents translated include wills, ${ }^{35}$ a land cession, ${ }^{36}$ documents regarding the right to inheritance, ${ }^{37}$ a petition for a guardian, ${ }^{38}$ a manumission,,$^{39}$ and a letter from the Prefect of Egypt regarding soldiers condemned for desertion..$^{40}$ Such translations are introduced or otherwise annotated in terms familiar from earlier periods. It is common for them to begin with a heading stating that they are a translation: e.g. "translation of a will," 41 "translation of the Latin" ${ }^{42}$ or "translation of a manumission." ${ }^{43}$ In a few cases, we have lengthier descriptions of the translation, its purpose and even its authorship. The phrase "as far as possible," standard in earlier Demotic-Greek translations, makes a recurrence, with some striking similarities in phraseology. A late second/early third-century $\mathrm{AD}$ translation of a Roman will is introduced as a "copy of a Roman will, translated as far as possible." ${ }^{44}$ The alienness of the Latin original is hinted at in another introduction, to a request for registration of an inheritance: "copy of this rightto-inheritance according to the custom of the Romans." ${ }^{45}$

A private letter from a man named Aurelius Artemidorus, recounting legal proceedings, describes a kind of text of which there are several preserved exam-

35 BGU I 326, AD 194, Karanis; P. Select 14, second century AD, Arsinoite nome; P. Diog. 9, AD c. 186-210, Philadelphia.

$36 S B \times X 14952$, second-third centuries AD, unprovenanced.

37 SB VI 9298, AD 249, Oxyrhynchus; P. Oxf. 7, AD 256-257, unprovenanced.

38 P. Oxy. XXXIV 2710, AD 261, Oxyrhynchus.

39 P. Oxy. IX 1205, AD 291, Oxyrhynchus.

40 P. Bagnall 8, AD 186-187, Mons Claudianus. I owe this reference to the anonymous reviewer.

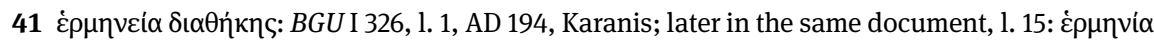

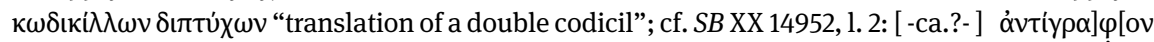
$\dot{\varepsilon}$ ] $\mu \eta \varphi ̣ \varepsilon i \alpha \varsigma$ [ -ca.?- ], "copy of a translation”; second - third century AD, unprovenanced.

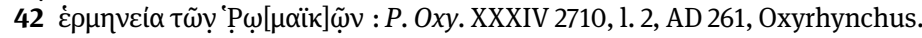

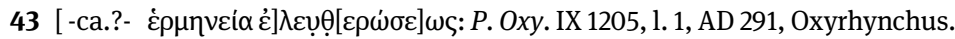

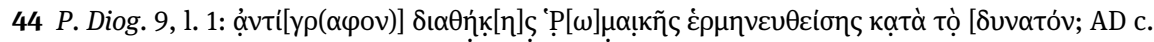
186-210, Philadelphia.

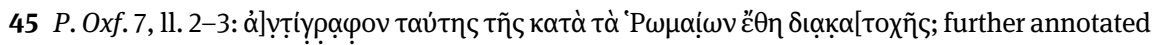

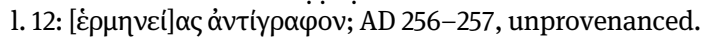


ples: a "document in which there is written both the Latin text and its translation." 46 We have three such examples of Latin texts which were translated into Greek at the same time, with the translation presented within the same document. These are the same kinds of texts as merited independent translations: a request for a guardian (P. Oxy. XII 1466, 1. 3; AD 245, Oxyrhynchus), a petition for succession to an inheritance ( $P$. Oxy. IX 1201, 1. 12; AD 258, Oxyrhynchus) and a judgement in proceedings before a praeses (P. Sakaon 34, 1. 15; AD 321, Theadelphia). In each case, the translation is introduced with the words "translation of the Latin"

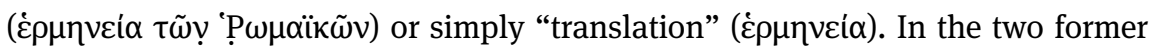
cases the translation is not verbatim and the Greek text contains further details, evidently relevant for the owners of the document, but superfluous in a Roman legal text.

The layout of these texts is interesting. In P. Sakaon 34, the translation is set off clearly in a separate column to the right of the main text, with the heading $\dot{\varepsilon} \rho \eta \eta v i ́ \alpha$ (sic) above it. P. Oxy. XII 1466 has the date and address in Latin at the top of the papyrus. There follows a blank space of the equivalent of two or three lines. Then, set against the right margin, comes the heading $\dot{\varepsilon} \rho \eta \eta \varepsilon \dot{\alpha} \alpha \tau \tilde{\omega} \nu$ 'P $\omega[\mu \alpha i ̈ \kappa \tilde{\omega} \nu]$. The Greek translation begins on the next line. In P. Oxy. IX 1201, we again find the Greek translation set apart, spatially, from the rest of the text, this time in a para-

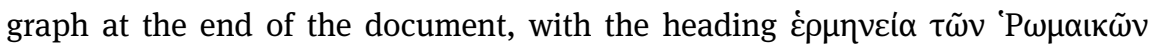
centred on the papyrus.

Only two translations name their author, in each case a "Roman notary" or

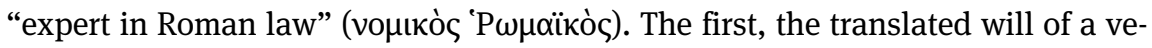
teran from late second-century AD Karanis, bears the subscription, in a second hand, "I Gaios Loukkios Geminianos, expert in Roman law, translated the above copy and it is in conformity with the original will." ${ }^{47}$ The second such subscription, in the same hand as the rest of its document, reads "I, Aurelios Aigyptos, and however I am styled, expert in Roman law, translated the above copy and it is in conformity with the original documents in the register and completed by me." 48 On the basis of their names, C. Lucius Geminianus would appear to be an Italian or Romanised immigrant from elsewhere in the Roman world, and Aurelios Aiguptos a local, of whatever ethnic origin. These two translators are testifying not

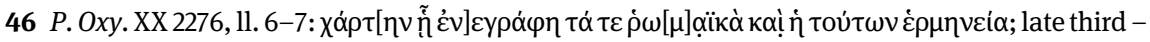
fourth century $\mathrm{AD}$, Oxyrhynchus.

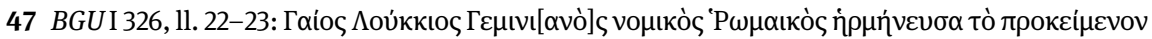

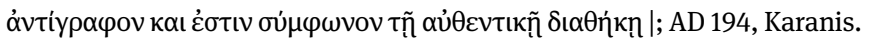

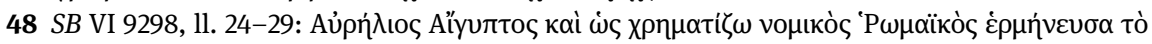

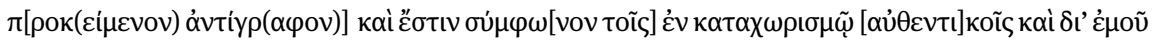
$\tau \varepsilon \tau[\varepsilon \lambda \varepsilon เ \omega \mu \varepsilon \dot{v}$ oเc]; AD 249, Oxyrhynchus. 
just to the fact that they produced the translation, but that it is in conformity with the original, according to Roman law. They were therefore either responsible for producing the Latin originals, or were very familiar with such documents from working in the legal profession. It is their legal expertise which is valued as a professional skill in these instances, more so than their literate linguistic expertise.

We might suggest that other translators do not sign their work in a similar way because their role was limited to that of translator. There was no reason to claim authorship of a translation in and of itself, unless one was also guaranteeing its legal validity. Those who are explicitly named as interpreters in the documentary or epigraphic record are almost always contributing some professional skill above and beyond their ability to render information in one language into another.

Another, non-legal, Latin-Greek translation from Egypt which names its author bears this out to a certain extent. A fragmentary literary text on papyrus, which may be an astrological ${ }^{49}$ or rhetorical treatise, concludes "Olympios Isidorianos ... translated (this) from the Latin." ${ }^{50}$ Olympios Isidorianos was not just the translator of the text, but must have had some professional or intellectual concern with its subject matter.

Finally, two documents which serve as a cautionary reminder that "interpret" does not always mean interpret in the linguistic sense, even in a translated document. In each case, an individual supplies extra documentation, or spells something out "so that I will not be misinterpreted" or "seem to misinterpret" (parermēneuein). In an amnesty decree of AD 212, the Emperor Caracalla clarifies and explains the content of a previous edict "so that no-one will interpret too narrowly my words from the earlier decree." ${ }^{51}$ Convicted offenders are guaranteed the right not only to return to their homeland, but to move freely throughout the Roman Empire, including the city of Rome. This decree, along with the two others which accompany it on the same papyrus, are of course themselves also translations from the Latin (just like I. Prose 65, the letter of Diocletian translated in an inscription from Elephantine discussed above), but we have no text preserved in this instance which mentions the process of translation or names the person responsible.

\footnotetext{
49 West (1974).
}

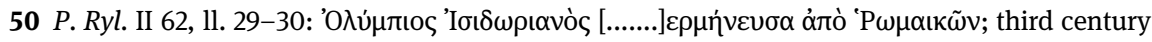
$\mathrm{AD}$, unprovenanced.

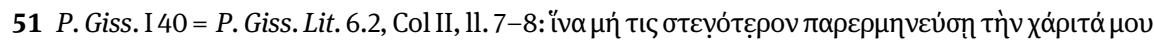

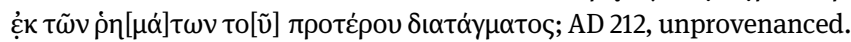


An early fourth-century AD petition to the logistēs of the Oxyrhynchite nome contains a copy of an earlier petition, which itself contains excerpts from the minutes (hupomnemata) of the first trial concerning the case before the Prefect $(P$. Oxy. XVIII 2187, AD 304, Oxyrhynchus). The reason for this conscientious quotation of the relevant documentation is, according to the petitioner, to avoid the perception that he has misinterpreted the facts:

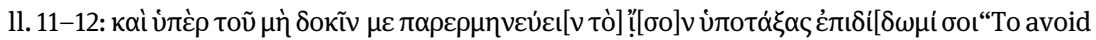
giving the impression that I am misinterpreting, I hand this petition in to you with a copy.”

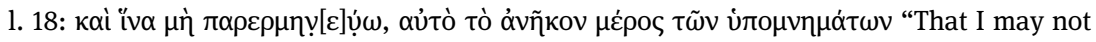
[seem to?] misinterpret, (I have attached to this petition) the relevant part of the memoranda."

The hupomnèmata of the first trial originally contained text in Latin, but rather than translate this, the writer has simply noted "text in Latin" (Rhōmaika) and omitted it (1l. 24, 28, 30). This practice is, according to Lobel, Roberts and Wegener (P. Oxy. XVIII), without parallel, and I have also been unable to find similar cases. But the reason for this omission is evident: the present document is not an original, but a duplicate which was to be handed over to the defendant, who would not have known Latin. The scribe chose not to translate, either because he was not able (which seems unlikely, if he was employed in some official capacity), because he could not be bothered (more likely), and/or because what the petitioner needed was a record that he had made a petition, with its contents, not a full account of the specific evidence which he cited in support of it.

\section{Hermēneis in the Zenon archive ${ }^{52}$}

Only a very few authors of written translations from Hellenistic and Roman Egypt are recorded by name, and none of these bears the title hermenneus. Our earliest attestation of individuals actually described as hermeneis comes from the thirdcentury BC archive of Zenon, from Philadelphia in the Fayum, which presents in microcosm some of the complexities and ambiguities of the material. This small cluster of four hermēneis (three of whom are named) has important implications for how we regard later, more isolated, attestations. One of our most important questions will be whether we can regard these hermeneis as interpreters in the

52 For an introduction to this archive, belonging to Zenon, estate-manager of the finance minister (dioikētēs) Apollonios, see Pestman (1981) and Clarysse and Vandorpe (1995). 
linguistic sense at all. Many of these individuals are demonstrably engaged in commercial activity, in which interpreting between languages played, if anything, an ancillary role. To what extent does the term hermèneus undergo an evolution or broadening in meaning, and may it refer to brokers or commercial agents for whom interpreting between languages was no longer a significant aspect of their job? Despite arguments to the contrary, ${ }^{53}$ this commercial aspect to the function of individuals referred to as hermēneis is present from the very beginning, in the Zenon archive.

The Zenon papers supply a disproportionate number of our named hermēneis from Egypt, across all periods. The key figure is one Apollonios, described as a hermēneus in three texts (P. Cair. Zen. I 59065, P. Ryl. IV 563, PSI IV 409). He appears in two letters to the dioikêtēs Apollonios. In one, a brief note of a few lines, he is the courier of a consignment of fish, sent to Apollonios the dioikētēs. ${ }^{54}$ He appears again in a slightly different context in a rather lengthier letter to Zenon, in which a man named Pataikion is concerned about a certain Egyptian soldier, who has travelled to make a petition against him before the dioikêtēs Apollonios. Pataikion tries to enlist Zenon's help in the matter, and mentions that he has also written to Apollonios the hermēneus about it. ${ }^{55}$ How is Apollonios expected to help? Was he involved in some way in the unspecified dispute, or is he expected to serve in a professional capacity as interpreter, intermediary, or some other area of expertise? In a further letter, Apollonios contributes six calves for the festival of the Pentaiterida. ${ }^{56}$ Apollonios the dioikētēs is mentioned in this document as well. It may well be that the principal reason Apollonios' title as herméneus is recorded in each of these cases is to differentiate him from his namesake. ${ }^{57}$ Such is, however, not the case for Limnaios, a hermēneus recorded in a list of dues payable by owners of flocks of sheep and goats..$^{58}$ None of the other individuals in this account bears a professional title. A certain Glaukias is a more unambiguous example of a commercial hermēneus. In an account of income and expenditure, he receives 12 copper drachmas "for purchases," a transaction in which he seems

53 Westermann, Keyes and Liebesny (1940), 11.

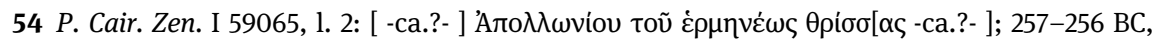
Philadelphia.

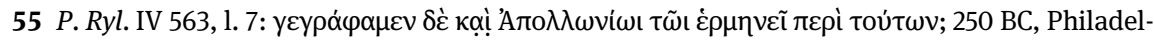
phia.

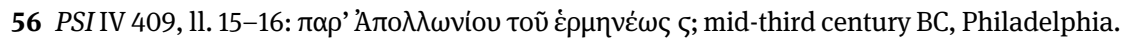

57 Wiotte-Franz (2001), 65.

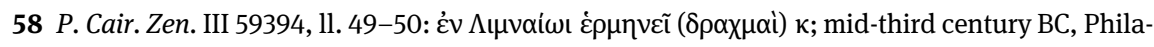
delphia. 
to have acted as a broker or agent. ${ }^{59}$ Similarly, the anonymous hermenneus (could this be Apollonios, Limnaios or Glaukias?) who is paid 3 obols for "guiding to garlic" is certainly being paid for sourcing produce. ${ }^{60}$

Whether any of these individuals is identical with persons attested elsewhere in the Zenon archive, it is almost impossible to say. In Clarysse's prosopography of the archive, ${ }^{61}$ homonymous persons are classified as far as possible, but in cases such as the present, where only the occupation is recorded, without patronymic or ethnic, we cannot really be sure whether any of these individuals also occur elsewhere, perhaps only under their given name. Apollonios is an especially common name: there are 37 persons so named in the archive. As noted above, Apollonios the hermèneus is never the sole Apollonios in any document in which he appears by this title, so it may be that his occupation here is not even pertinent, but simply mentioned to distinguish him from his namesakes. Limnaios is son of an Apollonios and also appears in P. Cair. Zen. III 59340, P. Lond. VII 2011, P. Mich. Zen. 66 and P. Wisc. II 78.

The editors of $P$. Col. Zen. II 63 "see no reason to regard these $\varepsilon \rho \mu \eta v \varepsilon$ เ [in the Zenon papers] as anything else than interpreters, conversant with the Egyptian language, who were useful in the daily dealings between the natives and those Greeks who did not speak the native tongue." 62 But the fact that the hermeneus in this text, Glaukias, is expressly paid "for purchases" does not help their argument. ${ }^{63}$ In fact, all of these hermenneis could be argued to be acting in some kind of middleman role, with no obvious connection to interpreting languages. This does not meant that they were not interpreters. On the contrary, linguistic skills (whether one's own, or hired from another) must have been essential to traders in a multilingual society such as Hellenistic Egypt. An epitaph of a Roman centurion from first-century AD Pannonia, to give a comparison, shows an army interpreter who was later able to translate his expertise into success as a merchant. ${ }^{64}$

We can be sure that language mediation, for commercial or official purposes, or simply to facilitate everyday social interaction, was constantly going on in Hellenistic and Roman Egypt. If a person was not themselves bilingual, they could make use of (or purchase) the services of someone who was. The comparative

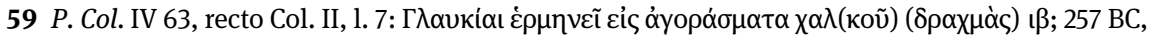
Philadelphia.

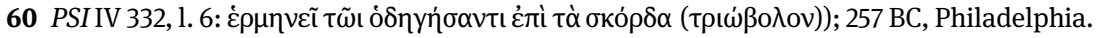

61 Clarysse in Pestman (1981); the hermenneis are listed in this prosopography as Apollonios (32), Glaukias (3) and Limnaios (2).

62 Westermann, Keyes and Liebesny (1940), 11.

63 Peremans (1983), 15; cf Crawford (1973), 352, on PSI IV 332.

64 Kolnik (1978); Mairs (forthcoming). 
scarcity of hermèneis in the papyrological record, however, indicates that such interpreting was for the most part, in and of itself, not considered worth mentioning; still less was someone who acted as an ad hoc interpreter perceived to have any defined professional role. This is true of all of the case studies considered in the present study. The contexts in which interpreters do appear in the Latin and Greek documentary record are those in which the interpreter's skills are part of a wider administrative, diplomatic or commercial remit. "Applied professional interpreting," not language skills on their own, or casual interpreting on an ad hoc basis, is what is worth mentioning.

If the hermēneis of the Zenon archive are brokers, we know nothing about their individual linguistic capabilities. Most of the hermenneis considered in the following sections have ambiguous roles. Although in some cases, such as with court interpreters, they can be demonstrated to have interpreted between languages, in the majority of cases they cannot. Some circumstantial connection with commercial activity is, however, very common. Like the English word "interpret," hermēneus and hermēneuein had a range of associated meanings in Greek. I see no need to argue either for a strict linguistic interpretation in every case, or that the frequent use of hermēneus to mean "broker" invalidates a linguistic reading of any particular text. The most straightforward explanation for the use of hermèneus to mean a broker or commercial intermediary in the papyri is that an original sense of "language mediator" - a person who would be very useful in facilitating transactions between Greeks and Egyptians - has broadened in colloquial parlance to mean a "mediator" in general. The term continued to be applied in a linguistic sense, as an oral interpreter or written translator, but it also became common to use hermēneus as a job title for a broker or trader.

In what follows, fragmentary texts and lack of detail can make it very difficult to distinguish which kind of activity a particular hermēneus is engaged in. My division of the material under subject headings is intended as a simple ordering device, not as a definitive categorisation - although I will give some assessment of what the available evidence suggests in each individual case. The texts discussed are arranged very roughly in order from the most obviously commercial, to the more probably linguistic. In general, however, I propose that the notion of linguistic interpreting is never entirely absent in any of these cases, even if a sense of commercial brokerage also becomes deeply engrained. As with the Latin-Greek translators considered above - who are named because they are legal experts, not solely because they are translators - the reason why commercial hermeneis have such prominence in the documentary record may simply be that economic transactions generate more paperwork than oral interpreting of a non-official nature. 


\section{The 'measure of the interpreter' (metros hermēneōs)}

A small group of twelve papyri from the early Roman period measure dry commodities such as dates and olives according to a "measure of the hermēneus" ( $\mu \varepsilon^{-}$ $\tau \rho \omega \dot{\varepsilon} \xi \alpha \chi 0 เ v i ́ \kappa \omega \dot{\varepsilon} \rho \mu \eta \nu \varepsilon ́ \omega \varsigma) .{ }^{65}$ This measure is a set one of six choinikes, around six metric litres. These texts belong to a fairly restricted local and temporal context, and so are, in a sense, easily "quarantined" from the others. All are from the Arsinoite nome, and date between AD 14 (P. Duk. inv. 85) and AD 151 (BGU I 227). The hermēneus is never named, and is always stated to belong to a particular village, whether generic ${ }^{66}$ or specific. ${ }^{67}$ In BGU XI 2123 (1. 7, AD 85, Arsinoite nome) we have an unfortunately-placed lacuna, so we do not know which locale was specified.

It seems evident that these hermēneis are - in this context at least - acting as some kind of village official, not as freelance brokers or privately-employed agents like the hermèneis of the Zenon archive. (Although perhaps they also did so on their own account, quite apart from their official regulatory duties.) Because our evidence for the "measure of the hermèneus" is so limited, we can say little more about their precise function. It is possible that, in the context of the first- and early second-century Arsinoite nome, a functionary with the title hermeneus took on something of the role of regulator of weights and measures played elsewhere in the Graeco-Roman world by the agoranomos - an official whose function in Hellenistic and Roman Egypt was closer to that of a public notary. ${ }^{68}$ As with the broker hermèneis of the Zenon archive, we have at present no evidence one way or the other as to whether this hermèneus who regulated local measures also acted as a formal mediator between speakers of different languages.

65 For a fuller treatment of the subject, see Mairs (2010).

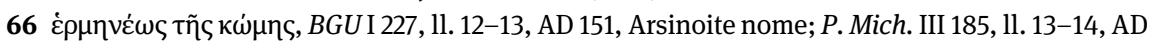
122, Bakchias; SB XIV 11718, 1. 11, AD 141, Tebtunis; the probable village is in each case named elsewhere in the document.

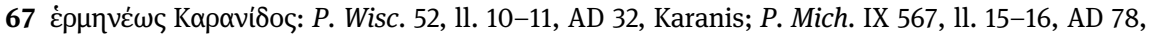
Karanis; BGU III 985, 1l. 9-10, AD 123, Karanis; P. Athen. 21, 1l. 10-11, AD 131, Karanis; BGU XIII

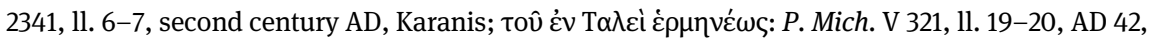

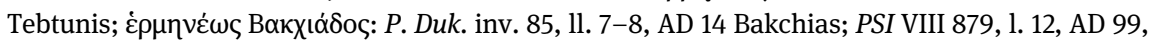
Karanis.

68 Raschke (1974). 


\section{Hermēneis and hermēneia in commercial and administrative contexts}

If hermèneia was a commercial activity, we could hardly expect it to have escaped regulation and taxation, which is precisely what we find in a tax-inspectors' report of the early second century AD. The report, addressed to the strategos of the Lykopolite nome, relates mainly to the grain trade, and the three senders are referred to as "inspectors of the tax on brokerage [telos hermēneias]." ${ }^{69}$ A further "inspector of brokerage," either also concerned with taxation or simply serving as some kind of superintendent, appears in a list of office-holders and the value of their property from Theadelphia. He is described as "inspector of brokerage of salt-dealers [hermēnias halopōliōn]."

A similar connection between hermēneis and -pōlai ("sellers," "dealers") concerns the "clothing-dealers and brokers [himatiopōlai kai hermēneis]" of $P$. Graux III 30. ${ }^{71}$ This text, a long register of receipts addressed to the state bank, mostly concerns the grain trade, but this section relates to the manufacture of garments for the state, such as clothing for prisoners. The trade corporations responsible for this receive payment in advance through the public bank of Arsinoe. That the clothing-dealers are also described as hermèneis indicates that their involvement in the garment trade goes beyond point-of-sale employment. They are in fact overseeing what, in modern management practice, would be described as a "vertically-integrated" enterprise, in which much of the chain of supply is owned and supervised by a single management team. The clothing-dealers are advanced funds for the manufacture of textiles and they are involved right up to the point of arranging shipment of completed garments by river transport. ${ }^{72}$

We have, unfortunately, far less information on the activities of most of our papyrological hermēneis than on these clothing-brokers. The term often appears in isolation, for example with the name of an "interpreter" listed as payer or

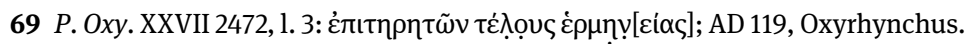

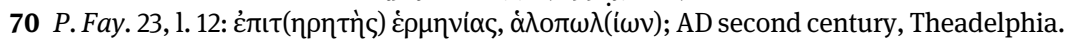

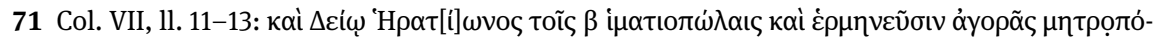

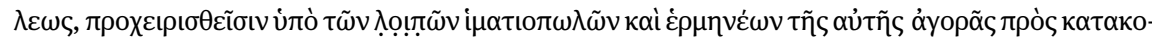

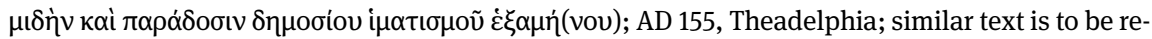
stored in Col. VII, 1l. 2-3. Kambitsis (1997, 60) suggests a similar reconstruction in BGU VII 1564, 11.

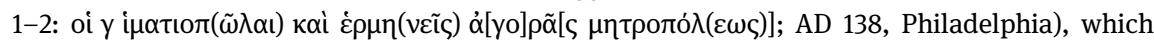
seems to me eminently plausible.

72 See Kambitsis (1997), 9, 60-65. 
payee in an account or receipt. Sometimes, circumstantial evidence indicates quite strongly that this person is a commercial broker of some sort. There is more to be gained from providing a frank assessment of the problems involved in assessing the activities of such hermēneis, than from any attempt at ruthless categorisation.

To illustrate the problems we are dealing with in deciding what kind of hermenneus a particular individual might be, I give the extended example of $P$. Oxy. XIV 1650 (late first century - early second century AD, Oxyrhynchus), a short set of accounts relating to the transport of wheat to Memphis by water which includes two items of payment to a hermèneus. It was found together with another document (P. Oxy. XIV 1650a), concerning the transport of beans. It has been suggested that the documents are accounts of customs duties payable at point-ofshipment, ${ }^{73}$ but the variety of items of expenditure suggests rather the accounts of a shipping agent, who oversaw all aspects of the shipping process for a client such as a major agricultural producer, or even the state.

Col. I

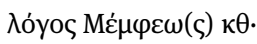

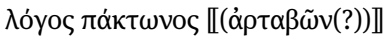

(

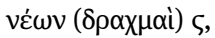
yévous ( $\delta \rho \alpha \chi \mu \alpha i) \delta$,

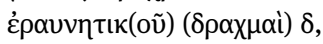

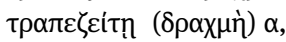

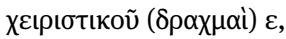
$\dot{\alpha} \lambda \lambda \alpha \gamma \tilde{\eta}(\varsigma)(\delta \rho \alpha \chi \mu \grave{\eta}) \alpha$, $\dot{\varepsilon} \rho \mu \eta v \varepsilon เ \varsigma(\delta \rho \alpha \chi \mu \alpha i) \beta$,

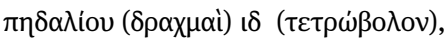

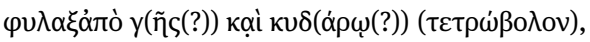

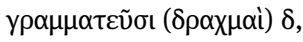

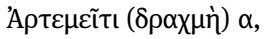

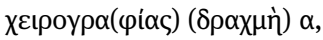

\author{
Memphis account, the 29th. \\ Account of a light boat: \\ 550 artabas of wheat, 44 drachmas, \\ boats $^{74} 6$ dr., \\ $\operatorname{tax}^{75} 4 \mathrm{dr}$., \\ inspection tax $4 \mathrm{dr}$., \\ to the banker $1 \mathrm{dr}$., \\ payment for a manager $5 \mathrm{dr}$., \\ exchange $1 \mathrm{dr}$., \\ to a hermēneus $2 \mathrm{dr}$., \\ 10 \\ helmsman's fee ${ }^{76} 14 \mathrm{dr} .4 \mathrm{ob}$., \\ a guard from the land and on the boat 4 ob., \\ to clerks 4 dr., \\ to Artemeis 1 dr., \\ written report $^{77} 1 \mathrm{dr}$., \\ 15
}

73 Johnson (1936), 606, No. 351.

74 Grenfell and Hunt (P. Oxy. XIV) translate "repairs," but "boats" or "boat equipment" seems a more probable translation, especially given the position of this item at the very head of the list. Johnson (1936), 606, suggests "wharfage" which is also plausible.

75 For genos as a form of tax, corresponding to the telos of other documents, see Grenfell and Hunt (P. Oxy. XIV), 91.

76 Lit. "rudder."

77 Or "affidavit." 


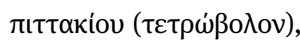

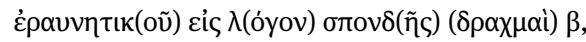

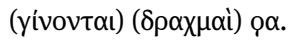

Col. II

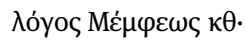

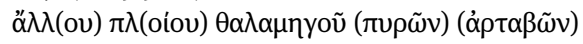
$\varphi \mu \llbracket(\delta \rho \alpha \chi \mu \alpha i) \mu y \rrbracket$ 20

$\dot{\omega} \varsigma \tau \tilde{\omega} v(\dot{\alpha} \rho \tau \alpha \beta \tilde{\omega} v) \rho \dot{\rho}(\delta \rho \alpha \chi \mu \alpha i) \eta(\delta \rho \alpha \chi \mu \alpha i) \mu \gamma$,

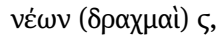

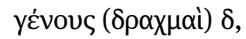

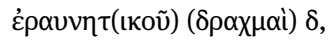
$\tau \rho \alpha \pi \varepsilon \zeta \varepsilon i \tau(\eta)(\delta \rho \alpha \chi \mu \grave{)}) \alpha$, $\chi \varepsilon\llcorner\rho เ \sigma \tau \iota \kappa о \tilde{~(\delta \rho \alpha \chi \mu \alpha i) ~} \varepsilon$, $\dot{\alpha} \lambda \lambda \alpha y \tilde{n} \varsigma(\delta \rho \alpha \chi \mu \grave{)}) \alpha$, $\dot{\varepsilon} \rho \mu \eta v \varepsilon \tilde{i}(\delta \rho \alpha \chi \mu \alpha i) \beta$, $\pi \eta \delta \alpha \lambda i ́ o v(\delta \rho \alpha \chi \mu \alpha i) ~ เ \delta$ ( $\pi \varepsilon v \tau \dot{\beta} \beta о \lambda o v)$,

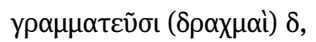
30

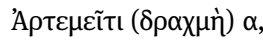

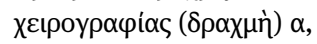

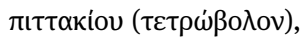

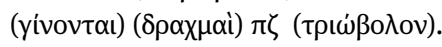

receipt 4 ob., inspection tax on account of the fee ${ }^{78} 2 \mathrm{dr}$., total $91 \mathrm{dr}$.

Memphis account, the 29th.

Another boat with a hold: 540 artabas of

wheat

at $8 \mathrm{dr}$. per 100 art., $43 \mathrm{dr}$, boats $6 \mathrm{dr}$.,

$\operatorname{tax} 4 \mathrm{dr}$., inspection tax $4 \mathrm{dr}$.,

to the banker $1 \mathrm{dr}$.,

payment for a manager $5 \mathrm{dr}$., exchange $1 \mathrm{dr}$.,

to a hermēneus $2 \mathrm{dr}$.,

helmsman's fee 14 dr. 5 ob.,

to clerks 4 dr.,

to Artemeis $1 \mathrm{dr}$.,

written report $1 \mathrm{dr}$.,

receipt 4 ob., total $87 \mathrm{dr} .3$ ob.

The two columns of the text relate to two different shipments of wheat of roughly similar volume. The various expenses associated with these shipments are, as might be expected, more or less identical and are listed in the same order. They begin with a charge by volume for the shipment ( 8 drachmas per 100 artabas) - is this the shipping agent's basic fee? - followed by an itemised list of expenses for various incidental fees, the payment of workers and administrative personnel, and the cost of the necessary paperwork. There is a method to the composition of these accounts, and the set rates and identical order of the lists indicate that the person who drew them up was well accustomed to doing so and had his own set working practice.

The appearance of the hermèneus (1l. 10 and 28) is not the only thing which is unclear about these accounts. Who, for example, is Artemeis? What is involved in the charge for "exchange"? Grenfell and Hunt find plenty of other things to occupy their commentary to the text and do not even mention the hermenneus, although they translate his title as "interpreter." Johnson, in contrast, translates as "bro-

78 For spondē as a payment or official fee rather than a libation, see P. Oxy. 1285, 1.16; P. Oxy. 101, 1. 19; P. Oxy.1207, 1. 10. 
ker."79 As with many of the other hermèneis I will consider in the following discussion, there are a few obvious starting-points in trying to establish what his role in the process involved. How, for example, might his activities relate to the other items of expenditure? In the present case, costs are listed for services, fees, and both manual workers (the helmsman, the guard who takes care of the shipment on land and on the boat itself) and administrative personnel (the banker, the clerks). The hermenēus might conceivably be anything from an interpreter who facilitates the co-operation of personnel who speak different languages, to a broker or foreman in charge of the shipment, to a state official or tax inspector overseeing the process who must be paid a fee. In the present account, similar kinds of expenditure are sometimes listed together: for example, those relating to written administration go towards the end of the list. So we might rule out the possibility that our hermēneus is engaged in producing written translations of documentation. That he is listed between entries for "exchange" and a helmsman does not help us especially. We can only make the fairly generic statement that he played some role in facilitating the shipment.

On balance, it seems likely that the hermèneus listed in P. Oxy. XIV 1650 can be considered to have played some commercial role - possibly or indeed probably also involving linguistic expertise, if he had to deal with the authorities and with various workers - but we cannot say for certain. There are a few other cases in which we can cautiously conclude that the role of a particular hermeneus was probably commercial. A hermēneus features as recipient of a payment in an account relating to wine in $O$. Bodl. II $1835 .{ }^{80} \mathrm{~A}$ brief text concerning the sale of a donkey concludes that it has been transacted "through Artemidoros, the hermeneus," again suggesting but not absolutely confirming a role as commercial broker. ${ }^{81}$ On the other hand, no scribe is named, and Artemidoros could possibly have been a literate official, employed for his expertise in writing Greek for an Egyptian-speaking clientele (on interpreting between spoken Egyptian and written Greek, see below).

We have another instance of a sale, in this case of cattle, transacted through a hermēneus in SB XVI $13071 .^{82}$ The situation here is still more confused. The relevant passage reads:

79 Johnson (1936), 606, No. 351.

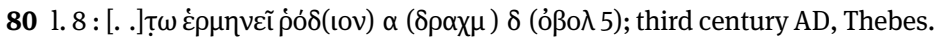

81 Stud. Pal. XXII 101, 1. 11: di]a \0Artemidw\%rou e9rmhne/wj; second century AD, Ptolemais Euergetis.

82 AD 223-235, Arsinoiton Polis. 


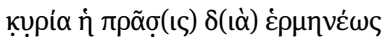

غุ[ $[\pi \eta] \rho \omega \tau \eta \dot{\theta} \eta \eta$ kạ̣ ò $\mu o ̣ \lambda \eta \sigma \varepsilon v$

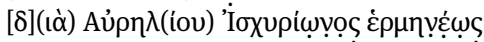

The phrase "through an interpreter" appears twice, the second time with the interpreter's name: Aurelios Iskhurion. Bastianini suggests that "of the agora" (áyopãc) can be read in the traces of the following line, and translates hermenneus as "scrivano pubblico" 83 - although this is an opportune moment to recall the more obviously commercial "clothing-dealers and hermēneis of the metropolitan agora” of $P$. Graux III 30 (AD 155, Theadelphia). Despite Lewis' translation of lines $18-19$ as "through an interpreter he was asked and agreed," 84 taking $\delta(เ \grave{\alpha}) \dot{\varepsilon} \rho \mu \eta-$

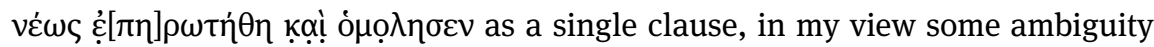
remains. It is also possible to split the clauses at the end of line 18: "the matter was taken care of through the interpreter; he was asked and agreed through the interpreter Aurelius Iskhurion.” This would give the "interpreter" some legal role in certifying the sale, albeit one which is not otherwise attested at this period.

SB XVI 13071 is by no means the only case which could be argued in several different ways. As noted above, I prefer to draw attention to the ambiguity of the sources in such cases, rather than attempt to shoe-horn intractable evidence into a rigid schema. A late second-century AD listing of five brief receipts for payments by one Eutuchos son of Eutochos includes two entries of payments for hermé-

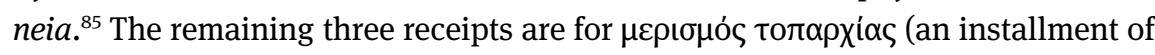
a toparchy tax? - the phrase is otherwise unattested), each payment also of 4 drachmas. These would seem to be payments of an official nature, but what is meant by hermēneia? Could it be a duty on trade, or simply "translation" of documents?

The hermèneus of P. Stras. VII 612 (Tebtunis, second century AD) is an intermediary in one sense at least. The author of the letter complains that he has sent two letters (to which he has presumably received no response), one through a

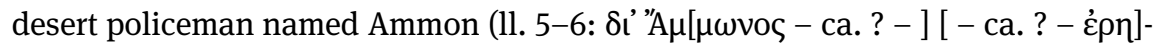

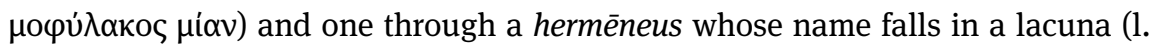

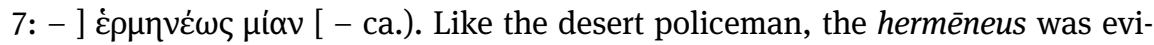
dently someone travelling in the right direction, with whom a letter could be sent. This would fit well with the idea of a "broker-hermēneus," travelling on business. But the earlier example of the "hermèneus of Trogodytes" Apollonios, which we

83 Bastianini (1984), 76.

84 Pap. Flor. 19, Vol. II, 348: I owe this reference to the anonymous reviewer.

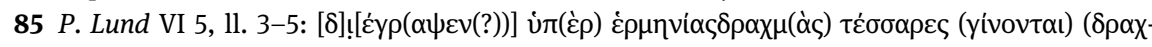
$\mu \alpha i)$;; AD 187-191?, unprovenanced. 
will now discuss, reminds us that trade on the desert fringes of Egypt could involve dealings with peoples whose indigenous language was neither Egyptian nor Greek: ${ }^{86}$

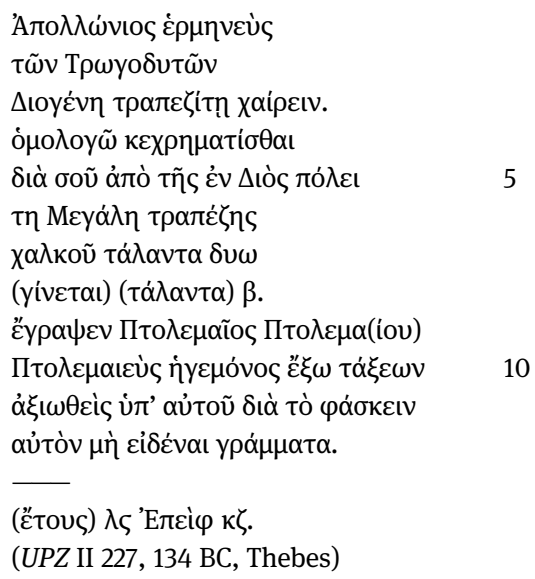

Apollonios the hermēneus of Trogodytes, to Diogenes the banker, greetings. I acknowledge having received through you, from the bank at Diospolis Magna (Thebes), two bronze talents, making 2 talents. Ptolemaios son of Ptolemaios, from Ptolemais, officer of reserve troops, ${ }^{87}$ wrote for him when asked, because he says that he is illiterate. Year 36, Epeiph 27.

In a receipt addressed to the banker Diogenes, Apollonios acknowledges having received two bronze talents from the bank at Thebes. Because he is illiterate, a military officer named Ptolemaios writes for him. The clause is a standard one, found often in a society with pre-modern rates of literacy (on interpreting for illiterates, see further below). As an illiterate, and also because the language of the Trogodytes had no written form, Apollonios was evidently not a translator of written texts. Almost all modern commentators have - rightly in my view - regarded him as an oral interpreter between Greek and the language of the Trogodytes. ${ }^{88}$ But, as we will discuss below, this was not his only professional role.

86 Rochette (1995).

87 On this military title, see Van't Dack (1969). It appears to refer to an officer of troops "outside" regular military service in some way, perhaps as veterans in a reserve force. The reason for the switch to the genitive, if this refers to Ptolemaios is unclear: a mistake, or does the title belong to

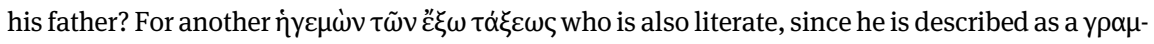

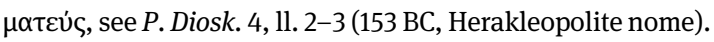

88 For a summary of earlier scholarship, see Rochette (1995), 62. 
Trogodytes (or Troglodytes) were the population of the eastern desert between the Nile Valley and the Red Sea coast, extending far to the south towards Ethiopia. ${ }^{89}$ Greek graffiti from sites such as El Kanais on the desert routes record the dedicants' thanks to the god Pan for having returned safe "from among the Trogodytes." 90 The term appears on an amphora from the Red Sea port of Quseir al Qadim, ancient Myos Hormos. ${ }^{91}$ We know little about the Trogodytes and do not know what language they spoke, although they are included by Plutarch in his list of the peoples with whom Cleopatra VII was supposedly able to converse without an interpreter (Plut. Ant. 27.3). A small number of individual Trogodytes also appear in papyri from the Nile Valley. ${ }^{92}$ The Prosopographia Ptolemaica records eight, who bear a mixture of Greek and Egyptian names, where these are preserved. ${ }^{93}$ But Trogodytes - like a number of other nominally ethnic groups in the papyri from Hellenistic Egypt ${ }^{94}$ - are not always Trogodytes. The term, while ethnic in origin, acquired an extended meaning, relating to members of a special

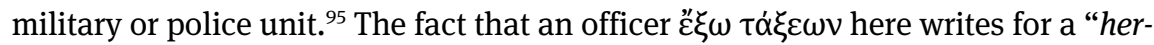
mēneus of Trogodytes" must therefore be treated as significant.

If Apollonios and Ptolemaios were colleagues, then this suggests that Apollonios interpreted with Trogodytes in a military context, as a member of a military unit either containing Trogodytes or which interacted extensively with them. It is also possible that he was a functionary involved in Ptolemaic economic management of the eastern desert and Red Sea trade. In relation to this, it would be interesting to know the purpose for which Apollonios borrowed money from the bank at Thebes. As Rochette notes, ${ }^{96}$ the very fact that Apollonios' title of hermèneus is mentioned in a document to which it bears no direct relevance suggests that it was a relatively important one, with some kind of official basis. In conjunction with the use of Trogodytes as a military unit, I therefore incline towards the interpretation that he was a military officer who interpreted for Trogodyte troops. Public banks might pay state workers, which provides a possible context for the payment he receives from Diogenes the banker. ${ }^{97}$ Although a Greek name may con-

89 On Trogodytes, see Pierce (2012), 228-231.

90 Bernand (1972); see also the discussions in Adams (2007) and Mairs (2010).

91 Tomber (2005), 41, Fig 3.

92 Rochette (1995), 63

93 La'da (2002), 297.

94 E.g. “Arabs,” Clarysse and Thompson (2006), Vol. II, 175-176.

95 See Clarysse and Thompson (2006), Vol. I, 222, for discussion and further references.

96 Rochette (1995), 66.

97 Parsons (2007), 119. 
ceal a more complex ethnic background in Egypt of this period, I also incline towards the view that he was a Greek who had learnt something of the Trogodyte language. This is what the genitive "of Trogodytes" appears to signify; had he been a Trogodyte himself, he could have been described as such, as our other examples of Trogodytes in the papyri show. ${ }^{98}$

Apollonios may have been illiterate, but there are other cases in which a hermenneus either appears, or is stated directly, to have played a literate role. The ambiguity of the term remains: some of these could also be construed as brokers in addition to or instead of interpreter-clerks.

In the account P. Oxy. XIV 1650, discussed above, the other items suggested strongly that the hermeneus listed was a commercial agent of some sort. Another list of expenses excavated at the site of Kellis in the Dakhleh Oasis, suggests something else entirely:

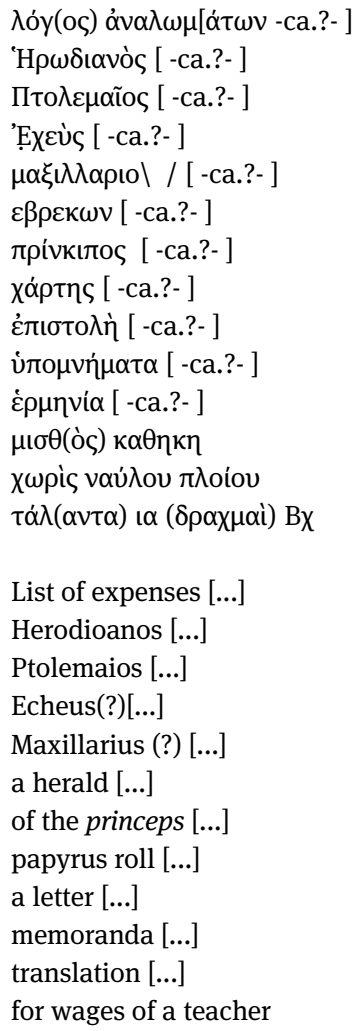


not including the costs of transportation by boat,

11 tal(ents), $2600 \mathrm{dr}$ (achmae).

(P. Kell. I 53, AD fourth century, Kellis; trans. Worp.)

As the editors of $P$. Kell. I note, there is a very strong case to be made here that hermenneia refers to translation. The expenses seem to relate to official business involving the production of one or more written documents. As well as personal names, and two Latin official titles, we have a papyrus roll, a letter, memoranda and the wages of a teacher. Although it literally means "guide," the sense of

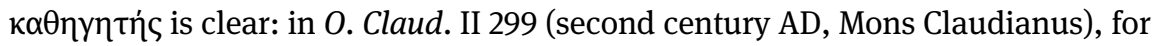
example, a student writes to his father, asking him to pay a teacher (kathēgètēs) to copy out a prose work for him. The teacher, presumably, has to travel from somewhere in the Nile Valley, hence the need to specify that the part of his journey by boat is not included in the listed costs. The editors suggest, plausibly, that the text relates to the costs of translating into Greek a text originally written in Syriac, Coptic, or Latin, or vice versa. We might add that Latin is the most likely, given the mention of two officials with Latin titles (princeps - possibly the chief of staff of a provincial governor - and praeco), and possibly one Latin personal name (Maxillarius). Do we have here the related costs for the production of one of the Greek translations of Latin documents discussed above?

The connection of another hermeneus with the Roman imperial administration is more overt. Described as a "interpreter and secretary," hermēneus kai grammateus, Papiris (?) commissioned an inscribed dedication to Isis on behalf of the Emperor Trajan and the imperial family, at Berenike on the Red Sea coast (O. Berenike II 121, AD 113-117; the block was found re-used in a later structure):

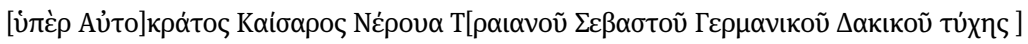

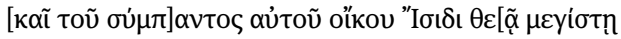

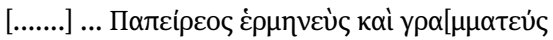

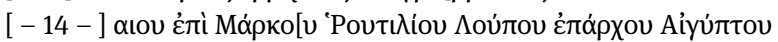

- . . - . . . . . . . . . .

On behalf of the fortune of Imperator Caesar Nerva Trajan Augustus Germanicus Dacicus and all his house, to Isis the very great goddess ... (son of?) Papiris, interpreter and secretary ... under Marcus Rutilius Lupus, prefect of Egypt.

(Trans. Bagnall, Helms and Verhoogt 2005, No. 121.)

Papeireos could be either the Roman nomen "Papirius," or a patronymic in the genitive from the Egyptian name "Papiris." 99 Any additional title (perhaps mili-

99 Bagnall, Helms and Verhoogt (2005), 27-28. 
tary) he may have borne is missing in the lacuna at the beginning of 1.4 . That he is a grammateus in addition to a hermēneus places him in a literate administrative role, although whether "interpreting" was part of this activity or complementary to it is not clear. Berenike was a port and the Roman army had a presence in the eastern desert, so Papiris (as I will call him for simplicity's sake) could plausibly be connected with the administration of either the army or the port, or both. This rules out neither sense of hermēneus, as interpreter or commercial broker. If he were an interpreter in the linguistic sense, his presence at Berenike opens the possibility that he could have interpreted anything from Latin, to Egyptian, to Trogodyte, to Sabaean or Tamil. ${ }^{100}$ The direct juxtaposition of the titles grammateus and hermèneus seems to argue most strongly for the sense of "written translator," a capacity in which he produced documentation in both Latin and Greek for Roman administration of the port.

Another hermèneus who appears in some kind of official administrative capacity is the "hermēneus of the stratēgos" of SB VI 9406. ${ }^{101}$ In this account of an estate-manager named Eirenaios, the "hermèneus of the stratēgos" is paid 9 drachmas; those closest to him in the text are door-keepers, bankers and a superintendent of a wrestling school. I would suggest here that the hermenneus working in the office of the stratēgos is an interpreter or translator, similar to what was suggested for Papiris, above, but this is, as ever, by no means certain. Perhaps more explicitly secretarial is the hermenneus listed alongside a notary in P. Oslo III $183,{ }^{102}$ but here we have too little information on this text's purpose to make further suggestions.

There are other examples where our evidence that a specific hermèneus was a bureaucrat of some sort is circumstantial at best. A hermēneus features as payee in a list of expenses, under the heading "Account of artisans;" 103 the list continues with a cashier (diastoleus), a clerk (grammateus), an attendant (hupēretēs), expenditure on food and a teacher (grammatikos) named Didymos. In another list concerning the distribution of wine, perhaps on the occasion of a festival, ${ }^{104}$ a hermeneus is listed along with a clerk of the Procurator (grammateus epitropou), an agoranomos, an advocate (rhētōr), a princeps, a "royal attendant" (boèthos basilikou) and finally a stratēgos. P. Berl. Leihg. II 39, a private account from Theadelphia, mentions a payment to a hermēneus of 4 drachmas (Recto 1. 108: 108: $\dot{\varepsilon} \rho \mu \eta-$

100 On texts in Indian languages from Egypt, see Salomon (1991).

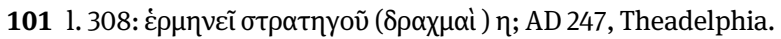

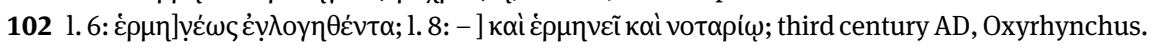

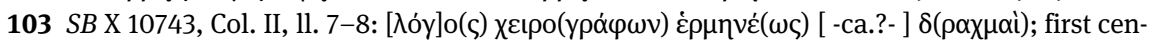
tury $\mathrm{BC}$ - first century $\mathrm{AD}$, unprovenanced.

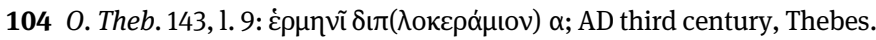




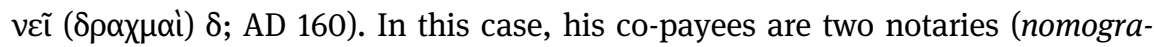
phos), a nomophulax, a woman named Lysania, an unnamed girl, a "superintendent of ferrying" (epitēerètēs porthmeiou), an attendant (hupēretēs) and an actuary. Commodities (beer and oil) feature in the list, too. The editors of the text suggest an interpreter with scribal function (P. Berl. Leihg. II, p. 109), which seems not inconsistent with this text and the others considered here. It is not certain that interpreting in the linguistic sense is meant in any of the above examples, but in each case I take the context as suggestive of it.

Earlier in this section, I discussed a document (SB XVI 13071) which con-

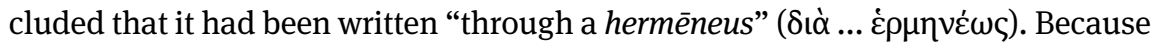
this was a commercial transaction, which appeared to state that the entire matter had been transacted through the hermèneus in question, we considered it alongside probable examples of hermenneis as commercial brokers, although noting that the role of the hermenneus could in fact be read in several different ways. A parallel to the concluding phrase of this document is offered by a census declaration from mid second-century AD Theadelphia, only in this case the evidence tilts more in favour of the hermenneus having played a literate administrative role. Here, the statement in question comes closer to the beginning of the document, stating that the document has been written through the "hermenneus of the village." 105 It should be noted that the reading of hermeneneus is not entirely secure. Does this suggest that the writer wrote in Greek from the declarations of parties who spoke only Egyptian? ${ }^{106}$ It is possible that this is to be considered alongside the examples discussed below of interpreting between oral Egyptian and written Greek.

Finally, two mentions of translation, or failure to do so, in administrative letters. In P. Paris 70, a very fragmentary letter possibly containing the reprimand of an official to a subordinate, we appear to find the phrase "they did not translate." ${ }^{107}$ Does the text perhaps contain a reprimand for failure to translate documents? The necessity of translating features in another fragmentary letter, possibly administrative, in which a sender whose name (terminating in -nnos) is not preserved writes to his "brother" Aurelius Aoustos. ${ }^{108}$ Some reference is made to an earlier letter sent by the author, and shortly afterwards comes the relevant phrase "... I had to translate ..." ${ }^{109}$ It is unclear what kind of document is to be translated: a legal or administrative document of some kind (cf. the Latin-Greek

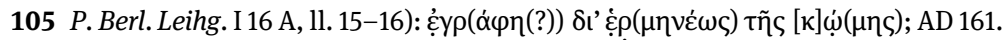

106 Hanson (1991), 177.

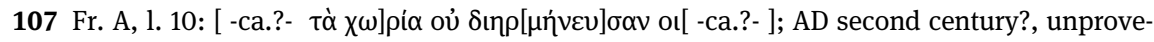
nanced.

108 P. Stras. IV 253, first half of the third century AD, unprovenanced.

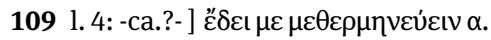


translations discussed above), or a personal letter, to be translated aloud (below)? The former is perhaps the most likely, and the option apparently preferred by Misslin in P. Stras. IV who notes it as an "allusion à une traduction du latin." If

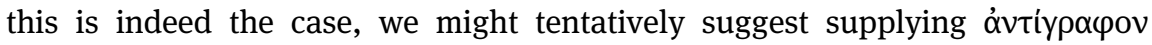
"copy" in the following lacuna, but a restoration on the basis of one preserved letter is really not much of a restoration at all.

\section{Unclassifiable examples}

In many of the cases considered in the previous section, there was little hard evidence on which to base a decision to classify a particular hermèneus as an interpreter in the linguistic sense, or as another kind of mediator. This is why I left most of the discussions relatively open. In still other cases, we really have no evidence, even the most circumstantial, as to the activity and social position of a hermēneus. For the most part, these are instances where an individual is listed, with his occupation, in a document such as a census or tax register in which he appears in his capacity as a private individual, not in a professional role. We have a hermèneus named Haryotes, who was charged 4 drachmas for a document prepared at the grapheion of Tebtunis. ${ }^{110}$ The other individuals in this document are also identified by their profession, so Haryotes is named as a hermēneus purely to identify him, not because he is engaging in any acts of interpreting or brokerage. In another, contemporary, register of documents prepared at the Tebtunis grapheion we find a hermēneus named Kronion, who had a land lease drawn up. ${ }^{11}$ Equally uninformative are a tax register from Karanis; ${ }^{112}$ a tax list from Oxyrhynchus in which a hermēneus pays tax on oil;113 and a list of proposals for municipal liturgies from Panopolis. ${ }^{114}$ The latter case is perplexing, because the title here stands in the place we would expect a personal name elsewhere in this document. I have not been able to find any other examples of "Hermeneus" as a personal name - which does not of course mean that it did not exist. A hermēneus named Iakob appears in an unprovenanced list, by occupation, of debtors dating

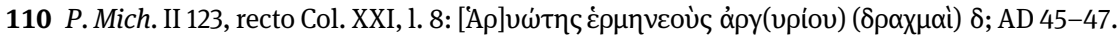

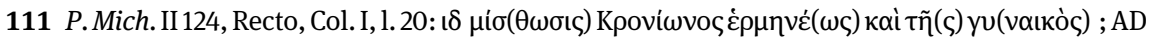
46.

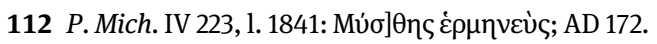

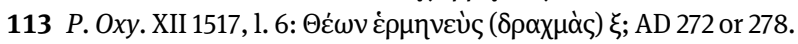

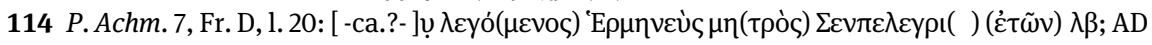
196. 
to the fifth or sixth century AD. ${ }^{115}$ Finally, a hermenneus "from the village of Peentalis" appears in a Hermopolite land lease of c. AD $602^{116}$; the lacunae make it unclear whether this hermeneus refers to one of the parties of the contract, or has some other role in the transaction.

We may know some of these men's names - Haryotes, Kronion, Musthes, Theon, Iakob - but we know little or nothing else about them. Sometimes the reference is not even to a specific hermēneus. A Ptolemaic composite tax-register from Athenas Kome in the Arsinoite nome lists the number of practitioners of each occupation in the village, and includes a single hermēneus. ${ }^{177}$ Here, even the reading of the occupation is "highly dubious". ${ }^{118}$ More dubious still are two fragmentary or abbreviated occurrences of the letters $\varepsilon \rho \mu$, for which the editors cautiously suggest readings relating to hermēneis or hermēneia, while noting that there are several other possibilities. P. Louvre I 26 (AD 145, Soknopaiou Nesos), a receipt,

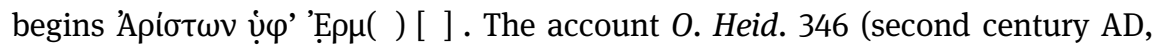
unprovenanced) twice contained the letters $\varepsilon \rho \mu$ abbreviated before a sum of

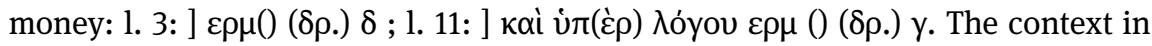
both cases is commercial, but I include these references for the sake of completeness, not because I believe that a connection with hermêneia here is to be assumed.

\section{Interpreters and the law}

Lest it seem that none of our papyrological hermenneis is unambiguously and exclusively involved in mediating between different languages, I introduce here some material where language medation is demonstrably involved. There is just one possible example from the Hellenistic period of a witness deposition delivered orally in Egyptian being translated/interpreted into written Greek, but this text is fragmentary and the sense is by no means clear. ${ }^{119}$ In a number of texts from the Roman period, however, we have explicit reference to the use of interpreters to enable parties and witnesses in legal cases to communicate with the presiding authorities. There are some examples, too, from Late Antiquity, of the content of

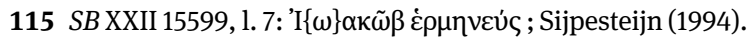

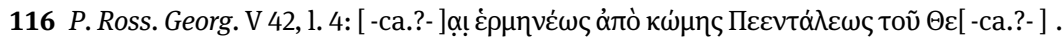

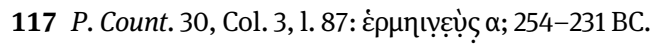

118 Clarysse and Thompson (2006).

119 P. Petr. II 17, fr. 2, 1. 4, 229-228 BC, Krokodilopolis; see further below on interpreting for women. 
Greek legal documents being orally rendered into Egyptian so that the parties can understand (see further below).

Once again, these cases are relatively few and far between, given the linguistic diversity of Egypt, and the fact that many of the population will have been monolingual Egyptian-speakers, incapable of communicating directly with the authorities in Greek or Latin. The silence of Egyptian court records of this period about the use of interpreters may appear striking, but is not unparalleled. In Cyprus under the Ottoman Empire, interpreters were similarly needed to allow people to use the Turkish-speaking shari' $a$ courts. ${ }^{120}$ As with our Egyptian material, however, these interpreters are mentioned relatively infrequently, and little is known about them. Non-Muslim subject populations under the Ottoman Empire were permitted to use their own courts, but for certain matters - including criminal cases, property transfers and disputes between Christians and Muslims - the Islamic courts had to be used. We might draw a parallel with the dual legal systems of Hellenistic Egypt, and the later compulsion to draw up certain legal papers in Latin. In court records from Cyprus, where a Greek-speaking population had frequent recourse to the Turkish courts, however, interpreters are only seldom mentioned: "although their presence in court cannot be disputed, their number, position, and identity have yet to be determined." ${ }^{121}$ A little more information is available on Ottoman court interpreters than those of Hellenistic and Roman Egypt, but the frustrations of dealing with the available evidence are the same. We might draw a little encouragement from the fact that Ottoman dragomans ( $\mathrm{di}$ van tercümanl) served as intermediaries between litigants and the courts, and also as interpreters: a useful model for the ambiguous, probably dual, linguistic and mediatory roles of many of our Egyptian hermēneis.

Eleven documents record the use of oral interpreters in Roman-period legal proceedings, mostly hearings before officials such as the Prefect, stratēgos, epistratēgos or defensor civitatis. ${ }^{122}$ The earliest reference dates perhaps to the early second century AD (SB XVIII 13156), but the rest of our court interpreters date between the late second and early fourth centuries AD. In each case, it is stated that a party spoke "through an interpreter" ( $\delta$ ’ $\dot{\varepsilon} \rho \mu \eta v \varepsilon ́(\omega)$ ). In only one case, the latest such document, is the interpreter otherwise identified ( $P$. Col. VII 175). The languages involved are never indicated, but then there is no practical reason why they should be. In the section above on written translation of legal documents, I outlined the benefits to mentioning that a translation had taken place. Above all

120 Çiçek (2002).

121 Çiçek (2002), 4.

122 Court interpreting in Roman Egypt is discussed briefly by Kelly (2011), 179-180. 
else, it was legally expedient, lest some question arise as to the accuracy of a translation or piece of testimony. The clause kata to dunaton might excuse or absolve the translator of inadvertent mistakes. A nomikos Rhōmaikos might swear to the accuracy of his translation. As well as the virtue of maintaining an accurate record of all that took place in a legal hearing - including the use of an interpreter - we should therefore also expect that the legal implications, and possible problems, of testimony delivered through an intermediary were a concern to all involved. What was important, in the few cases in which we have such statements, was to record that an interpreter had been employed, not the specific languages involved - which were, we should expect, almost always Egyptian and Greek. ${ }^{123}$

In some cases, we have no record of the names of the parties involved, usually because the text in question is fragmentary. ${ }^{124}$ Where the name of the person interpreted for is preserved, we find a mixture of Egyptian and Greek names, in dialogue with Roman officials. There is perhaps a small majority of Egyptian names, but in such a small sample, in a society in which people might bear more than one (Greek or Egyptian) name, we cannot regard this as statistically significant. Psaeis confesses to the Prefect Decimus Veturius Macrinus that he is not registered in the census. ${ }^{125}$ In a trial protocol of the second or third century AD, the name of a man called Psenesis, who had to speak through an interpreter, is the only one preserved. ${ }^{126}$ One Hermanoubis speaks through an interpreter, in an unfortunately damaged section of a dispute over division of an inheritance. ${ }^{127} \mathrm{~A}$ man named Antinous is questioned three times through an interpreter in an unprovenanced trial protocol of the third or fourth century AD. ${ }^{128}$

123 Bagnall (1993), 233.

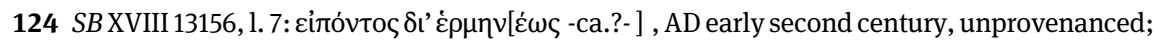

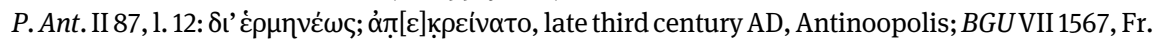

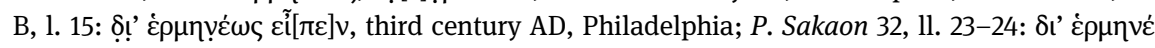

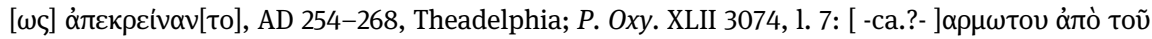

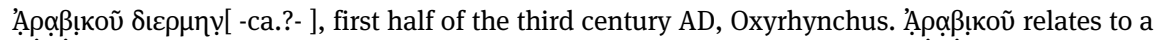
village of this name in the Aphroditopolite nome, fascinating though it would be to find evidence of interpreting for Arabs.

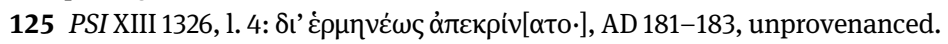

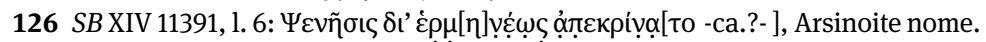

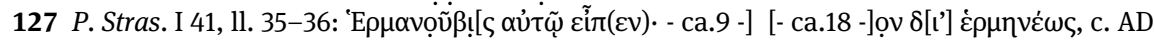
250, Hermopolis Magna. The names Ammonios, Antoninos, Sarapion and Horigenes follow on directly from this section, but these are in the accusative and refer to advocates, who appear and speak frequently elsewhere in the document, without any mention of interpreting. So the interpreting here is being done for Hermanoubis.

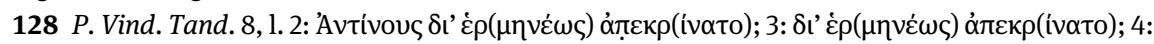
$\delta \iota^{\prime} \dot{\varepsilon} \rho(\mu \eta v \varepsilon \dot{\omega} \omega \varsigma) \dot{\alpha} \pi \varepsilon \kappa \rho(i ́ v \alpha \tau o)$. 
Our two most interesting cases, which provide the most detailed information on the interpreting process and the parties involved, are the well-known "Petition of Dionysia" 129 and a report of proceedings before the defensor civitatis about ownership of property. ${ }^{130}$ Dionysia's father, Chairemon, wanted to divorce her from her husband against her will. In support of her case, her petition cites earlier rulings. One, from the minutes of the epistratēgos Paconius Felix in the eighteenth year of Hadrian, concerns Taeichekis, whose father, Phlauesis son of Ammounis, wished to take her away from her husband, Heron son of Petaesis. An interpreter is used to ask what she herself wishes. ${ }^{131}$ All the parties involved have Egyptian names, and we should suppose that the language interpreted is Egyptian, into Greek. Yet the fact that Taeichekis is a woman may also be relevant to the act of interpreting. The question of a gendered aspect to language use in Hellenistic and Roman Egypt, and proportionately greater use of interpreters by women, will be considered below.

In only one recorded case is an interpreter in a legal proceedings named. According to the common, if perhaps counter-intuitive, pattern which emerges from much of our documentary evidence, from Egypt and elsewhere, this man is named as the interpreter responsible because his primary responsibility is actually something else. The speaker, Neilos, is directly addressed on several occasions in the report, and each time it is stated that he spoke through the same

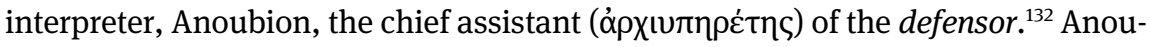
bion is listed along with all the other public servants present at the beginning of the document. Whether interpreting was a usual part of his professional remit, we do not know. But his employment as an interpreter in this case, whether habitual or a one-off, suggests the same as common sense: that bilingual officials present in some other capacity may often have been pressed into service as interpreter when required.

129 P. Oxy. II 237, AD 186, Oxyrhynchus; trans. Rowlandson (1998), No. 138.

130 P. Col. VII 175, AD 339, Karanis.

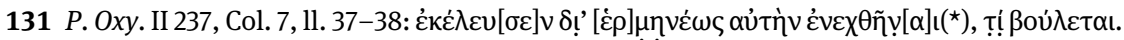

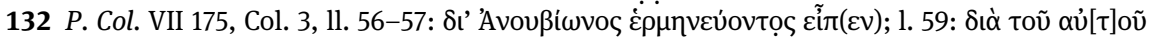

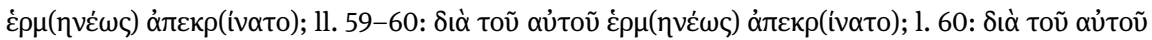

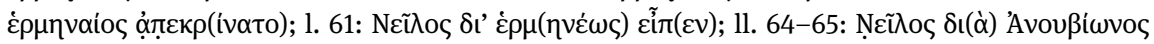

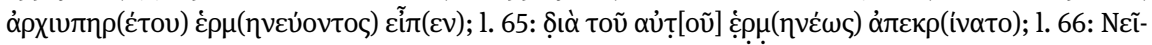

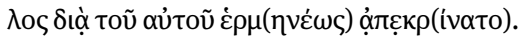




\section{Interpreting between oral Egyptian and written Greek}

Only at a relatively late date, and in five isolated cases (one of which is not clearcut), do we find explicit evidence for something which must have been a common occurrence: the reading aloud of a personal letter or official document to parties who did not know the language in which it was composed. ${ }^{133}$ In three out of five of these cases, the persons for whom the written Greek is translated into oral Egyptian are female. The question of whether women were disproportionately likely to need such services will be considered below.

In the first such example, a man named Ptolemaios writes to his sisters Zosime and Rhodous. The letter is in Greek, and begins "You, whoever you are, who are reading this letter, make a small effort and translate to the women what is written in this letter and tell them."134 This request to translate comes even before the greetings. As has been pointed out by more than one commentator, it is not just the linguistic repertoires of Zosime and Rhodous which are in question here: "Whether Ptolemaios knew Greek and could write it cannot be known. The style is certainly vivid enough to be his own, but as has already been pointed out by both editors, the hand is rather formal for a letter and could be that of a professional." 135 The matter of literacy is, in fact, crucial. In the second century AD there was no form of written Egyptian in common use which the writer of the letter could have employed, so the notion of a brother writing to his sisters in a language he knows they do not understand is not so perverse as it at first seems. ${ }^{136}$ Ptolemaios himself could conceivably have been a preferential user of Egyptian, as dependent upon the scribe he employed to write his Greek letter as his sisters were on the unknown person who would translate the letter to them.

The remaining four examples are rather later. P. Oxy. LXIII 4397 (AD 545, Oxyrhynchus) is a settlement of claims between Flavius Apion II and the monastery of Abbas Hierax; for the complicated back-story to this lengthy document, see

133 Hanson (1991), 177, also sees the scenario behind the production of P. Berl. Leihg. I 16 A and B as involving oral dictation in Egyptian and transcription in Greek, but here the evidence is less explicit.

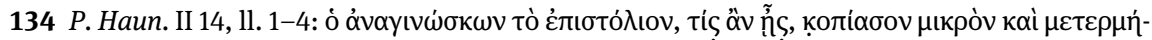

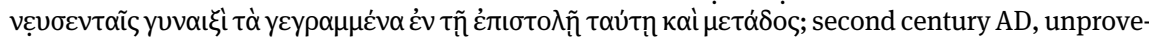
nanced; for a re-edition of the text, and full description of the contents of this letter, see BülowJacobsen and McCarren (1985).

135 Bülow-Jacobsen and McCarren (1985), 72.

136 Bagnall (1993), 234-236. 
the introduction to the text in P. Oxy. LXIII. In three places, it is noted that the legal clauses have been read aloud and translated to specific individuals or groups of monks, who are illiterate, so that they can assent. ${ }^{137}$ Pamouthios, who subscribes in Greek for the illiterate Egyptian speakers, is probably also the translator. Likewise, in a coda to a sale contract of AD 594, the women Aurelia Tsone and Aurelia Tseure assert that "When it was read aloud and translated for us into the Egyptian language and pleased (us), we expressed acknowledgement and executed (it)." ${ }^{138}$ Here, at least, the languages involved are stated outright. Similarly, Apa Abraham, Bishop of Hermonthis, had a will made in Greek in the early seventh century, which he had read back to him in Egyptian. ${ }^{139}$ Apa Abraham who was literate in Coptic, but not in Greek - dictated the will in Egyptian, and the notary Joseph, a local parish priest, wrote it down in Greek. ${ }^{140}$ (On interpreting in the Egyptian monastic literature, see the Appendix.) Later still, in AD 723, after the Arab conquest, we have the less clear-cut case of Elizabeth, daughter of Epiphanios and Maria, who states in her Coptic testament that "they read it to me in Egyptian; I heard it and I agree to it." ${ }^{141}$ Elizabeth is evidently an Egyptian-speaker, and most probably illiterate, but it is not obvious why it should be specified that she was read this Egyptian document in Egyptian.

In large part, of course, this translation of spoken Egyptian to and from written Greek is also a question of literacy, as I have already noted for the letter of Ptolemaios. The monks of P. Oxy. LXIII 4397 have the legal document read aloud to them and translated; we are told explicitly that they "do not know letters." Even if they could speak Greek - or even if, like Apa Abraham, they were literate in some form of Egyptian - the majority of people at all periods will not have been able to read and write it. The person who has to employ a scribe or signatory

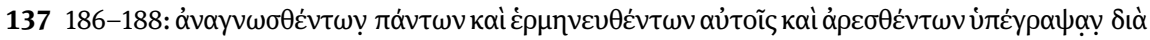

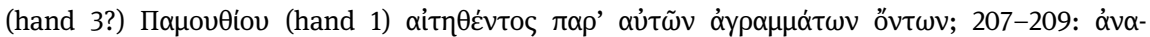

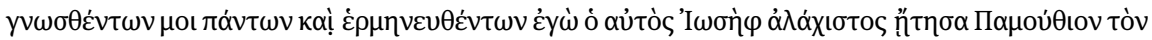

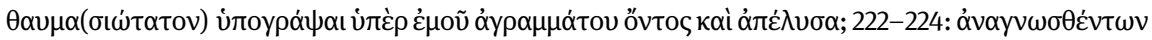

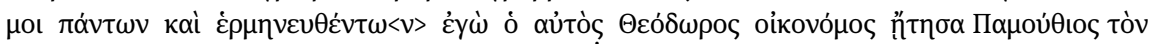

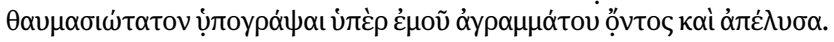

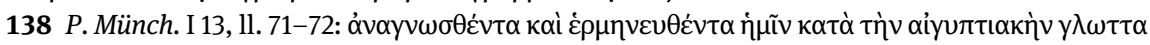

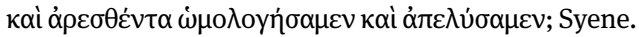

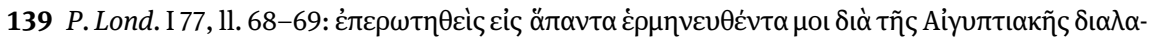

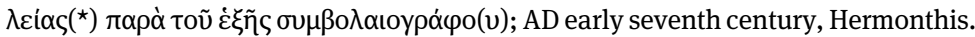

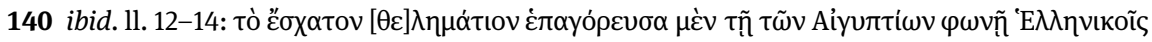

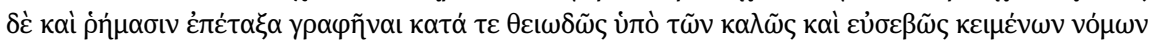

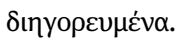

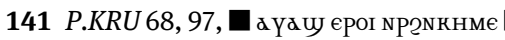


because they "don't know letters" is a common feature of the papyri, ${ }^{142}$ including two of our interpreters or clients of interpreters: Apollonios the "interpreter of Trogodytes" 143 and Aurelia Arsinoe, who submits a document requesting a guardian. ${ }^{144}$ Some of the witnesses to the testament of Apa Abraham state merely that they have heard the text of the will read aloud by its composer - we do not know whether in Greek or in Egyptian - not read it. ${ }^{145}$ On these and many other occasions, we should suspect that "not knowing letters" was synonymous with "not knowing Greek."

\section{Concluding remarks on chronology and geography}

I have chosen to present the evidence thematically, because I find no compelling evidence that there was any major evolution in the sense of the term hermèneus over time, nor that the provenance of the documents had much impact on what "type" of hermenneis were recorded. In the Zenon papyri, from the mid-third century BC, broker-hermèneis were already present, and we also see hermēneis and hermèneuein connected to translation and interpreting across all periods covered here. The terms had a reasonably broad semantic scope throughout. The only indication that hermèneus had a specific local sense in any context comes from the collection of references to a "six-choinix measure of the hermèneus" from the Arsinoite nome in the first and second centuries AD. Here, we perhaps find a villagehermēneus serving as a regulator of weights and measures, for which we have no evidence elsewhere.

142 Youtie (1971) and (1975); Hanson (1991).

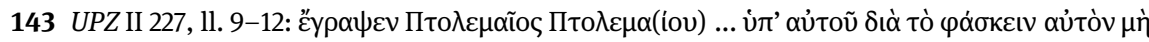

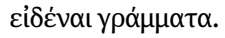

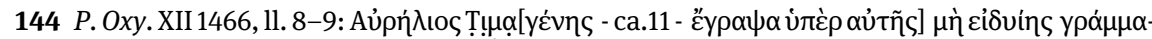
$\tau \alpha$.

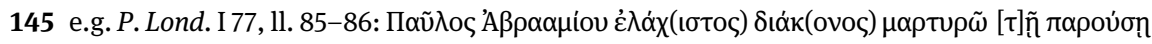

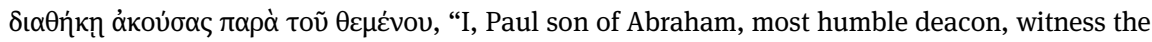
present will, having heard it from the one who drew it up." 


\section{Interpreting for women}

That there was a gendered aspect to bilingualism in Hellenistic and Roman Egypt appears a relatively common-sense proposition. The role of gender in shaping language use and transmission in bilingual societies is recognised in modern linguistics. ${ }^{146}$ The traditional notion of women as inherently linguistically and culturally conservative - as "guardians" of language or culture - has been effectively challenged by case studies, especially among endangered minority languages such as Breton or Scots Gaelic, ${ }^{147}$ where women appear as active agents of linguistic change. Accessing women's linguistic behaviour in the documentary record from Egypt is, of course, rather more difficult. It is not my intention to treat the subject in any depth here, but rather to examine what, if any, evidence there is to support the thesis that women (of all ethnic backgrounds) were more likely to be monolingual Egyptian speakers than men, and that they will therefore have made more frequent use of interpreters, in official and domestic contexts.

Male-biased gender ratios in the early Greek immigrant population under the Ptolemies, ${ }^{148}$ and consequent intermarriage between Greek men and Egyptian women, resulted over many generations in a nominally "Greek" population who in fact had a significant degree of Egyptian ancestry in the female line. Untangling the cultural and linguistic implications of this intermarriage is anything but straightforward. Women, like men, might bear double Greek-Egyptian names, and some might even operate in both Greek and Demotic literate spheres. ${ }^{149}$ Certainly there is no simple Greek-male-public versus Egyptian-female private divide within families of mixed descent. ${ }^{150}$ In Egyptian families who did not have any Greek roots at all, it may also be argued that men, with exposure to commerce and dealings with the authorities, are more likely to have learnt Greek than women. The question of whether women were disproportionately monolingual (or preferential) Egyptian speakers has been considered in most depth for the Roman period and Late Antiquity, but there is no consensus. In her analysis of Coptic and Greek documents from Aphrodite, MacCoull sees no significant relationship between gender and an individual's choice to employ a Greek or Coptic scribe: other factors, cross-cutting gender divides, emerge as more important. ${ }^{151}$ Bagnall and

146 Burton, Dyson and Ardener (1994); Piller and Pavlenko (2004).

147 McDonald (1994); Constantinidou (1994).

148 La'da (2002); Clarysse and Thompson (2006), Vol. II, 297.

149 E.g. the famous businesswoman Apollonia-Senmonthis of second-century BC Pathyris: Vandorpe (2002).

150 The problem is considered by Rowlandson (2004).

151 MacCoull (2004). 
Cribiore, in contrast, observe a shift among women letter-writers from Greek to Coptic, once Coptic becomes available as a means of written expression (Demotic having been out of common use for some time), suggesting that their preferred language of spoken communication had always been Egyptian..$^{152}$

Women appear as users of interpreters and generators of translations in many of the same contexts as men. In the petition of a woman named Lamiske regarding an alleged act of hubris, the statement of one of the witnesses, a woman with the Egyptian name Nephthikhis, contains a reference to interpreting or translating. ${ }^{153}$ The papyrus is fragmentary and the sense is not entirely clear. It is tempting to suggest that the deposition has been translated from her (spoken) Egyptian for recording in a Greek official written document, but there is a danger that Nephthikhis' gender and indigenous name may make us jump to conclusions. What, precisely, the "interpreting" or "translating" refers to is in fact uncertain.

Women involved in Roman legal cases, like men, sometimes had to be interpreted for. Despite the practical benefits of mentioning in the written record that interpreting had taken place, we should again suspect that this happened on a much more frequent basis than is recorded. The only example we have of a woman speaking through an interpreter in such a context is in fact the case cited by Dionysia, whose father wished to divorce her from her husband against her will. It is recorded that the woman in this previous case, Taeichekis, was asked, through an interpreter, what her own wishes were. ${ }^{154}$ It is generally - and probably correctly - considered that Taeichekis is an Egyptian-speaker, with insufficient Greek to communicate effectively at a judicial hearing. ${ }^{155}$ One might, of course, play devil's advocate and suggest that the interpreting here was between Taeichekis' Greek and the Latin of the presiding official, the epistratēgos Paconius Felix, but it seems unlikely that a Roman official hearing such cases in Egypt would be incapable of speaking Greek, even if he might choose not to. ${ }^{156}$ To what extent is Taeichekis' gender a factor here? Unfortunately, no mention is made of translation or interpreting in the statements and citation of documents - by Taeichekis, Dionysia or parties to any of the cases invokes - elsewhere in this text.

Legal cases involving women might be the subject of translations between Greek and Latin - a circumstance which had nothing to do with the gender of the

152 Bagnall and Cribiore (2006), 21-22.

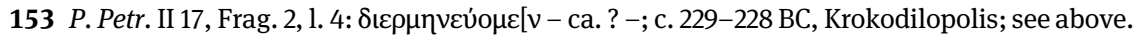

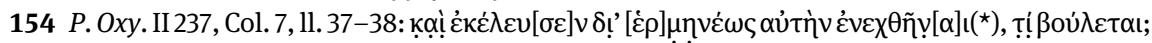
AD 186, Oxyrhynchus; trans. Rowlandson (1998), No. 138.

155 Youtie (1975), 205.

156 For the deliberate choice of Latin in such circumstances to assert Roman authority, see e.g. Adams (2003), 557-558, on P. Oxy. LXIII 4381, AD 375, and Wiotte-Franz (2001), 75-78. 
parties, and everything to do with the compulsory use of Latin for certain legal documents, in a society where the Latin language was not in common use by the majority of the population. Women here operate under the same legal and linguistic constraints as men. P. Oxy. XII $1466^{157}$ is a request for a guardian from a woman named Aurelia Arsinoe. A relatively brief Latin text - the part of the document with legal force - is in this case followed by a translation into Greek, headed

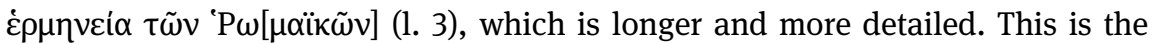
part of the document which would be of greater use for future reference to all those concerned, not just Arsinoe. An original Latin petition for release of a daughter from patria potestas is preserved only in its Greek translation. ${ }^{158}$ The woman in this instance has a dual Greek-Egyptian name, Aurelia Apollonia alias Tinutis, but the fact that she has had to commission a bilingual legal document bears no relation to her personal language use. Still less agency, linguistic or otherwise, is exercised by the slave Paramone and her children, who were manumitted by the Jewish community at Oxyrhynchus in AD $291 .{ }^{159}$ The original Latin manumission document inter amicos, which again is not preserved, was given a Greek translation which is clearly marked as such. ${ }^{160}$

Most previous discussion of women's language use and the question of interpreting for women has, however, centred around two particular documents which we have already noted, each of them an isolated case, around four centuries apart. ${ }^{161}$ A legal document from Syene in AD 594, in which two sisters, the Egyptian-named Tsone and Tseure, sell some property which they have inherited, concludes with the clause "when it was read aloud and translated for us into the Egyptian language and pleased (us), we expressed acknowledgement and executed (it)." ${ }^{162}$ The explicitness here is a welcome contrast to the vast majority of cases, where we can only make informed guesses - albeit usually quite secure ones - about which languages precisely were involved in an interpreting transaction. In this case it is spelled out for us: the Greek document is read aloud to the two women in Egyptian. It is tempting to regard this case as the tip of the iceberg: a rare written expression of an extremely common practice, whereby women (or

157 AD 245, Oxyrhynchus; trans. Rowlandson (1998), No. $140 \mathrm{~b}$.

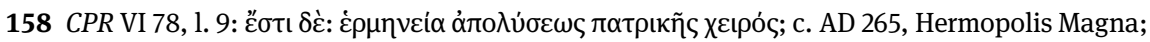
Arjava (1999).

159 P. Oxy. IX 1205, trans. Rowlandson (1998), No. 143, and Kraemer (2004), No. 56.

160 l. 1: [-ca.?- $\dot{\varepsilon} \rho \mu \eta v \varepsilon \dot{\alpha} \alpha \dot{\varepsilon}] \lambda \varepsilon v \underline{\theta}[\varepsilon \rho \omega \dot{\sigma} \sigma \varepsilon] \omega \varsigma$; the restoration appears secure.

161 Bagnall (1993), 234-236.

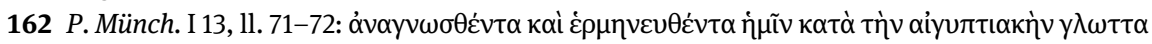

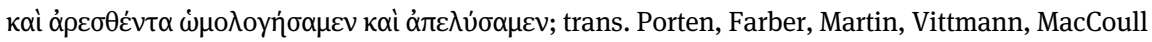
and Clackson (1996), D47. 
anyone else) who could not read and/or did not understand the language in which a legal document was drawn up, would have it read aloud to them in their own language, so that they could assent. This practice was not restricted to women. As Bagnall notes, ${ }^{163}$ the closest parallel to this document is the early seventh-century AD Greek will of Apa Abraham, Bishop of Hermonthis, which mentions that the Bishop dictated his text in Egyptian, had it recorded by the notary Joseph in Greek, then had the text read back to him in Egyptian so that he could agree. ${ }^{164}$ Likewise, most of the witnesses to the document state that they have heard it, not read it. We have also the similar clauses in P. Oxy. LXIII 4397 where the monastic community of Abbas Hierax have legal papers read to them and translated so that they can assent: these individuals are both illiterate and unable to understand Greek.

The second, earlier, document is, of course, the letter in which a man named Ptolemaios writes to his sisters Zosime and Rhodous, beginning: "You, whoever you are, who are reading this letter, make a small effort and translate to the women what is written in this letter and tell them." 165 This request to translate comes even before the greetings. Are the (Greek-named) women monolingual speakers of Egyptian, the language this family used in the home, whereas their brother has had the opportunity and necessity to learn Greek? The availability of Greek, but not Egyptian, as a written medium is an important factor here. Not just Zosime and Rhodous, but also Ptolemaios, might have been preferential users of Egyptian as a spoken language. Even in Pharaonic Egypt, where the common written language, for those who were literate, was Egyptian, differential rates of literacy between men and women created a similar scenario, where a personal letter might bear an address to a man, who was expected to communicate its contents to the woman to whom the text of the letter itself was addressed. ${ }^{166}$

I have tried to emphasise the variety of kinds of linguistic behaviour which may have lain behind each of these documents. The written word can often obscure personal oral language choices, and it also needs to be borne in mind that the vast majority of men, like women, will have been monolingual or preferential users of Egyptian. The crucial question is whether we choose to regard P. Münch. I 13 and $P$. Haun. II 14 as significant and representative of widespread informal or ad hoc interpreting for women, whose linguistic (and literate) repertoires may

163 Bagnall (1993), 235.

164 P. Lond. I77, 11. 12-14, 68-69, see MacCoull in Thomas and Hero (2000), 51-58.

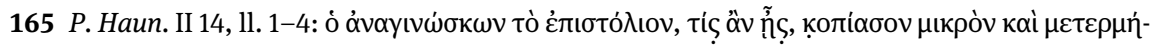

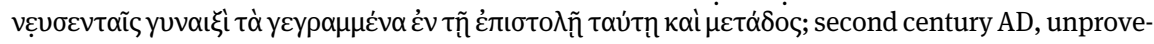
nanced.

166 Bagnall (1993), 235; Wente (1990), 9. 
have been different from those of their menfolk. I do not think that we can answer this question with any great conviction. All that can be said is that there is suggestive evidence both for women - even "Greek” women - in Egypt having a greater tendency to use only the Egyptian language; and for women's entanglement with the Ptolemaic or Roman bureaucracies and legal systems frequently necessitating the use of interpreters - whether or not these are ever mentioned. In the latter case, at least, women shared this need with men. In P. Col. VII 175, Neilos acts as representative for his wife Herais and her sister Taesis. By their names, we may suppose that the women were Egyptian-speakers, but even Neilos needed to use an interpreter.

\section{Interpreters and their clients: ethnicity and language use}

It would be interesting to be able to say something about the ethnic background and linguistic repertoires of interpreters and those who made use of them, but we are crippled by lack of data. It is frequently stated that, in the Hellenistic period, it was more common for Egyptians to learn Greek than vice versa. While this seems a sensible proposition - upwardly-mobile Egyptians might gain tangible social and economic benefits by learning the language of the dominant social and political group - it is difficult to back this up with hard evidence. The only named translator between Demotic (in this case probably spoken) and Greek is one Theon son of Theon, a "Persian of the epigonē." 167 Suggestions of linguistic interference in Greek translations of Demotic legal documents ${ }^{168}$ may, I would suggest, be a product of the translation process as much as the writer's dominant language.

We have a little more information on the background of those who produced translations between Greek and Latin, but still not much (see above). One translator, Gaius Lucius Geminianus (BGU I 326), is probably from Italy or one of the other Romanised and Latin-speaking provinces of the western Roman empire. The other named nomikos Rhōmaikos, however, Aurelios Aiguptos, is almost certainly a local Greek (and also Egyptian) speaker (SB VI 9298). Olympios Isidorianos, translator of a Latin astrological text, is also, by his name, a Greek (P. Ryl. II 62). One case which may reflect a common scenario is that of the assistant to the defensor civitatis Anou-

167 P. Heid. VIII 416; Clarysse (1994); see above.

168 Mussies (1968). 
bion, who acted as interpreter in a hearing for an Egyptian speaker ( $P$. Col. VII 175; above). Anoubion was present in his official capacity, but was also co-opted as interpreter. It is likely that junior officials in the administration, multilingual Egyptians or Egyptian-Greeks, were often pressed into service in this way.

As has already been discussed above, those who are recorded as having spoken through interpreters in legal hearings of the Roman period are marginally more likely to bear an Egyptian name than a Greek name. But nomenclature is an uncertain guide to either ethnic origin or language use, especially among women: the Greek-named Zosime and Rhodous ( $P$. Haun. II 14) needed interpreters or translators to deal with Greek speech or written material. Of the other named hermēneis, most bear Greek names - Haryotes (P. Mich. II 123) and possibly Papiris (O. Berenike II 121) are exceptions - in Greek documents. We do not know if they bore dual Greek-Egyptian names, as was fairly common, nor do we have any explicit record of their legal ethnic classification (such as that used in the census listings kat' ethnos in P. Count).

\section{Interpreters' pay}

In some cases, the services of individuals acting as interpreters were free: the unknown person who is politely requested to translate the letter for Zosime and Rhodous (P. Haun. II 14), or the chief assistant to the defensor civitatis, Anoubion, who probably receives no extra pay for his additional services as interpreter $(P$. Col. VII 175).

It might be expected that where we do have recorded the sums paid to hermenneis of whatever sort for their professional duties - or of sums paid by them for taxation or offerings - these might give some idea of their socio-economic status, in comparison to others paying or being paid in the same document. Tabulation of the relevant data, however, only makes it clear how hopelessly confused the matter is:

\begin{tabular}{|c|c|c|c|c|c|}
\hline Hermēneus & Reference & Date & Sum paid to & Sum paid by & $\begin{array}{l}\text { Range of } \\
\text { sums in the } \\
\text { same docu- } \\
\text { ment }\end{array}$ \\
\hline Apollonios & PSI IV 409 & mid $C 3 B C$ & & $\begin{array}{l}6 \text { calves } \\
\text { (contribution } \\
\text { for festival) }\end{array}$ & $1-6$ calves \\
\hline Limnaios & \multicolumn{3}{|c|}{$\begin{array}{l}\text { P. Cair. Zen. III mid C3 BC } \\
59394\end{array}$} & 20 dr. (tax) & $\begin{array}{l}\text { [Unmanage- } \\
\text { ably large } \\
\text { number] }\end{array}$ \\
\hline
\end{tabular}




\begin{tabular}{|c|c|c|c|c|c|}
\hline Hermēneus & Reference & Date & Sum paid to & Sum paid by & $\begin{array}{l}\text { Range of } \\
\text { sums in the } \\
\text { same docu- } \\
\text { ment }\end{array}$ \\
\hline Haryotes & P. Mich. II 123 & AD 45-47 & & $\begin{array}{l}4 \text { dr. (for } \\
\text { document } \\
\text { drawn up at } \\
\text { the gra- } \\
\text { pheion) }\end{array}$ & $\mathrm{n} / \mathrm{a}$ \\
\hline Glaukias & P. Col. IV 63 & $257 \mathrm{BC}$ & $\begin{array}{l}12 \mathrm{dr} \text {. 'for } \\
\text { purchases' }\end{array}$ & & $1-20 \mathrm{dr}$. \\
\hline $\begin{array}{l}\text { Anonymous "who } \\
\text { guided to the } \\
\text { garlic" }\end{array}$ & PSI IV 332 & $257 \mathrm{BC}$ & 3 ob. & & $\begin{array}{l}3 \text { ob. }-3 \text { dr. } 3 \\
\text { ob. }\end{array}$ \\
\hline Apollonios & UPZ II 227 & $134 \mathrm{BC}$ & $\begin{array}{l}2 \text { bronze } \\
\text { talents from } \\
\text { the bank }\end{array}$ & & \\
\hline Anonymous & $S B \times 10743$ & $C 1 B C-A D C 1$ & $\begin{array}{l}\text { [Not } \\
\text { preserved] }\end{array}$ & & $4-28 \mathrm{dr}$. \\
\hline Kronion & P. Mich. II 124 & AD 46 & & $\begin{array}{l}10 \text { ob. (for } \\
\text { document } \\
\text { drawn up at } \\
\text { the gra- } \\
\text { pheion) }\end{array}$ & $\mathrm{n} / \mathrm{a}$ \\
\hline Anonymous & $\begin{array}{l}\text { P. Oxy. XIV } \\
1650\end{array}$ & $\begin{array}{l}\text { AD late C1 - } \\
\text { early } C 2\end{array}$ & $2 \mathrm{dr}$. & & $4 o b-5 d r$ \\
\hline Anonymous & $\begin{array}{l}\text { P. Berl. Leihg. } \\
\text { II } 39 \text { R }\end{array}$ & AD 160 & $4 \mathrm{dr}$. & & $4-24 \mathrm{dr}$ \\
\hline Anonymous & P. Lund VI 5 & AD 187-91? & $4 \mathrm{dr}$. & & $4 \mathrm{dr}$ \\
\hline Anonymous & O. Theb. 143 & $A D C 3$ & $\begin{array}{l}1 \text { diplokera- } \\
\text { mion of wine }\end{array}$ & & $\begin{array}{l}\text { 1-5 diplokera- } \\
\text { mia }\end{array}$ \\
\hline Anonymous & $\begin{array}{l}\text { O. Bodl. II } \\
1835\end{array}$ & $A D C 3$ & $\begin{array}{l}1 \text { rhodion, } 4 \\
\text { dr., } 5 \text { ob. }\end{array}$ & & $\begin{array}{l}1 \text { rhodion - } 1 \\
\text { rhod., } 4 \text { dr., } 5 \\
\text { ob. }\end{array}$ \\
\hline $\begin{array}{l}\text { Anonymous "her- } \\
\text { mēneus of the } \\
\text { stratēgos" }\end{array}$ & SB VI 9406 & AD 247 & $9 \mathrm{dr}$. & & $\begin{array}{l}\text { 9-16 dr. (v } \\
\text { long account, } \\
\text { so only in } \\
\text { section near } \\
\text { hermēneus) }\end{array}$ \\
\hline Theon & $\begin{array}{l}\text { P. Oxy. XII } \\
1517\end{array}$ & AD 272 or 278 & & $\begin{array}{l}60 \mathrm{dr} . \\
\text { (tax on oil) }\end{array}$ & $40-120 \mathrm{dr}$ \\
\hline
\end{tabular}


Lacunae or uncertain readings within the documents themselves in most cases make meaningful comparisons with other persons in the same document difficult. In terms of comparing hermēneis with each other, the chronological and geographical spread of the documents make this a fairly futile task. If we add into the equation the fact that we often do not know precisely what duties a hermeneus was paid for, and for what length of time, then it is really impossible to say anything of any significance about these figures. The fact that the hermeneus Apollonios is by far the biggest donator of calves in PSI IV 409, for example, may tie in with our impression of him as a person of some importance, who was approached for help by the petitioner of P. Ryl. IV 563. But in none of these cases can we use financial figures to situate hermèneis and their activities in a meaningful social context.

\section{Appendix: interpreting in a monastic context}

I have already discussed the Greek will of Apa Abraham, Bishop of Hermonthis, which states that he dictated it in Egyptian to be recorded in Greek, and that it was then read back to him in Egyptian to check (P. Lond. I 77); and also the Greek settlement of claims which was read aloud and translated to illiterate Egyptianspeaking monks in the monastery of Abbas Hierax (P. Oxy. LXIII 4397). Quite apart from the business of the translation of scripture and religious texts between Greek, Coptic and other languages, the coming together of people into monastic communities, in Egypt and elsewhere, must frequently have required the use of interpreters. I do not intend to provide a full survey of language use in Egyptian monastic communities ${ }^{169}$ - nor of the much wider question of language use in Late Antique and early Islamic Egypt. ${ }^{170}$ But a few references to interpreting in Christian hagiographical literature from Egypt give some idea of the continuing need for interpreting between Greek and Egyptian, and the range of meanings which the verb hermèneuein and its derivatives continued to have.

Our clearest attestations of interpreting between languages in an Egyptian monastic context come from texts originally composed in Greek; subsequent Cop-

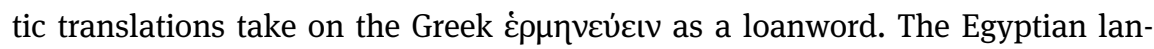
guage, at all periods, presents even greater difficulties than Greek in clarifying the actual meaning of terms which are translated into modern languages as "inter-

169 Some pertinent pieces of evidence are discussed by Torallas Tovar (2010), 35-42.

170 See Papaconstantinou (2010). 
preter." The only work to treat the subject at length is an unpublished PhD thesis by Bell, which deals for the most part with individuals described as i'3w in relations between Pharaonic Egypt and Nubia and western Asia. ${ }^{171}$ It is difficult to escape the conclusion that none of the terms Bell discusses actually principally mean "interpreter" at all, although those so described may have operated in more than one language. ${ }^{172}$ As Redford points out, the Egyptian verb which most closely approximates to the English "interpret" is whe ("loosen, unravel, explain, interpret"173). This becomes the Coptic oyw2, with a similar range of meanings and degree of ambiguity. ${ }^{174}$ Cerný notes the curious absence of the verb wh' from Demotic texts, ${ }^{175}$ but it is likely that the older wh ${ }^{\circ}$ has simply become the Demotic w3h, with a similar range of meanings. In Demotic, the verb wḥm is sometimes rendered as 'interpret' in modern translations. It has the meanings of "repeat, answer, mean, signify, explain.” But I have been unable to find any instances in which any if these terms is used in the sense of interpreting or translation between different languages.

One of the Sayings of the Desert Fathers (c. fifth century AD) $)^{176}$ recounts an interpreting-related miracle. Apa Johannes and a group of monks visited Apa Poimen in Syria, and wanted to talk to him:

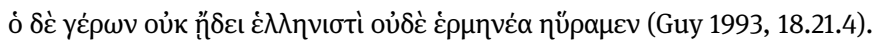

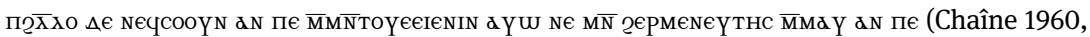
No. 188).

“...but the old man did not know Greek, and no interpreter could be found.”

God, fortunately, intervened to help them do without an interpreter, and when he saw that they were at a loss, Apa Poimen (who was probably a Syriac speaker) miraculously started to speak Greek. This is not, however, the only sense in which "interpreting" appears in the Sayings of the Desert Fathers. It is more common, in fact, for the verb hermèneuein or the noun hermèneia to appear in the sense of interpreting or expounding the meaning of a teaching or parable. ${ }^{177}$

171 Bell (1976).

172 See the useful clarification in Redford (1986), 125-126.

173 Cf. Bell (1976), lxxxii.

174 Crum (1939), 508b.

175 Černý (1976), s.v. oyw2.

176 Ward (1975).

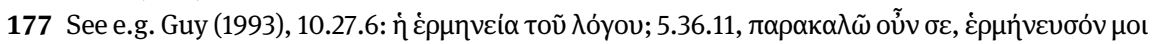

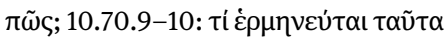


Two panegyrics of Egyptian holy men mention interpreting between languages under similar circumstances to one another. In each case, this is part of an established hagiographical trope of the simple, desert-dwelling Egyptian holy man, challenged by sophists who argue in Greek, who is able to thwart them through his holiness, simplicity and common sense.

St. Anthony (d. c. AD 356), an early pioneer of the desert hermit lifestyle, spoke only Coptic. His Greek Life was written by Athanasios of Alexandria around $\mathrm{AD}$ 360, although it received its widest circulation in a later Latin translation by Evagrius of Antioch. On three occasions, Athanasios mentions that Anthony spoke to visiting Greek intellectuals, who attempted to mock him, through interpreters. ${ }^{178}$ At the same time (72.3), it is mentioned that Anthony was illiterate. Although it is doubtless true that Anthony was both a monolingual speaker of Egyptian and an illiterate, the rhetorical emphasis which Athanasios places on both fits very much within the context of his programme of depicting Anthony as a simple ascetic.

The same theme makes an appearance in the Panegyric of Makarios, Bishop of Tkōw (d. 451/452). This work was probably originally composed in Greek, but survives in translations in the Sahidic and Bohairic dialects of Coptic and in Arabic. The surviving Coptic manuscripts date to the ninth and tenth centuries AD. If the attribution to Dioskoros is correct - which it is probably not - then the Greek original was composed in the first half of the fifth century AD; Johnson prefers to date it somewhat later, ${ }^{179}$ but no absolute date can be fixed. Makarios is another humble, Egyptian-speaking holy man, who is reliant on interpreters during his journey to the imperial court at Constantinople. On the sea voyage, Dioskoros says that he invited Makarios to come and sit with him, but had to resort to beckoning, since Makarios did not understand what he was saying. When Makarios does come over to him, "I, too, would not have understood his speech if Peter, the deacon, had not interpreted (hermèneue) his speech for me, for he knew the Egyptian language." ${ }^{180}$ Another priest sitting nearby refers disparagingly to Makarios as "mouthless," and is soundly ticked off by Dioskoros for his lack of respect. Later, after their arrival, Makarios is summoned to the emperor and is nearly refused admission because of his shabby dress. When he is finally allowed in, he wants to berate the emperor for tolerating the "blasphemies" being uttered by Nestorios, "but he did not find anyone who would dare to interpret (ehermeneue)

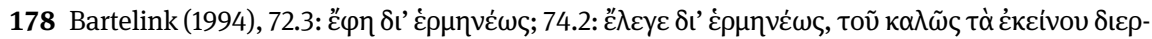

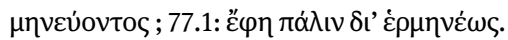

179 Johnson (1980), 9-11.

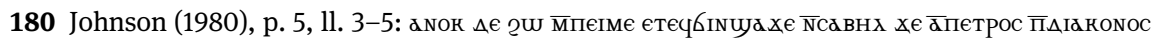
¿ермнnеүе 
for him what he was saying." 181 The helpful bystanders who had presumably translated the discussion for him up until this point are suddenly moved to dis-

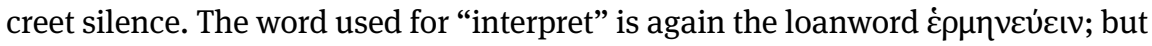
as in most Coptic texts, especially translations from the Greek such as this, Greek loanwords are very common, even of basic non-technical vocabulary (cf. toloma "dare" in the same sentence). In this depiction of an Egyptian holy man in the corrupt metropolis, there is a very intentional contrast between the heresies and sophistry of educated Greek discourse, and the straight-talking and humility of the Egyptian ascetic, just as in the Life of Anthony.

Each of the cases discussed here treats interpreting as a relatively normal, straightforward occurrence, even if they use their descriptions of interpreting to make a rhetorical point. It seems to be expected that bilingual bystanders or colleagues can interpret when necessary, and not being able to find someone to interpret is an annoyance. This, perhaps, was close to the experience of persons in the bilingual society of Hellenistic and Roman Egypt, who needed to deal with speakers of different languages in the course of everyday life, below the level at which we find interpreters attested in our official sources. These are the kind of interpreters who do not often get mentioned in the papyri.

\section{Biliography}

Adams, C. "Travel and the perception of space in the eastern desert of Egypt." In Wahrnehmung und Erfassung geographischer Räume in der Antike, edited by M. Rathmann, 211220. Mainz am Rhein: Philipp von Zabern, 2007.

Adams, J. N. Bilingualism and the Latin Language. Cambridge: Cambridge U. P., 2003.

Arjava, A. "Eine Freilassung aus der väterlichen Gewalt, CPR VI 78." Tyche 14 (1999): 15-22.

Bagnall, R. S. Egypt in Late Antiquity. Princeton: Princeton U. P., 1993.

Bagnall, R. S. and R. Cribiore. Women's Letters from Ancient Egypt, 300 BC-AD 800. Ann Arbor: University of Michigan, 2006.

Bagnall, R. S. and P. Derow. The Hellenistic Period: historical sources in translation. Oxford: Blackwell, 2004.

Bagnall, R. S., C. Helms and A. M. F. W. Verhoogt. Documents from Berenike Vol. 2: texts from the 1999-2001 Seasons. Brussels: Fondation Égyptologique Reine Élisabeth, 2005.

Bartelink, G. J. M. Vie d'Antoine (Athanase d'Alexandre): introduction, texte critique, traduction, notes et index. Paris: Cerf, 1994.

Bastianini, G. “Una vendita di animali: P. Vindob. G 31583.” ZPE 56 (1984): 73-78.

Bell, L. Interpreters and Egyptianized Nubians in Ancient Egyptian Foreign Policy: aspects of the history of Egypt and Nubia. Unpublished Thesis. University of Pennsylvania, 1976.

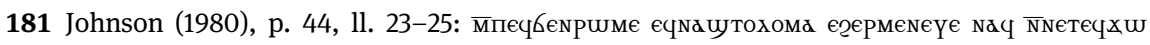
ммооу. 
Bernand, A. Le Paneion d'El-Kanaïs: Les inscriptions grecques. Leiden: Brill, 1972.

Brennan, P. "Diocletian and Elephantine: a closer look at Pococke's puzzle (IGRR 1.1291 = SB 5.8393)." ZPE 76 (1989):193-205.

Bülow-Jacobsen, A. and V. P. McCarren. "P. Haun. 14, P. Mich. 679, and P. Haun. 15: a re-edition." ZPE 58 (1985): 71-79.

Burton, P., K. Kushari Dyson and S. Ardener, editors. Bilingual Women: anthropological approaches to second language use. Oxford: Berg, 1994.

Calderini, R. “De interpretibus quaedam in papyris.” Aegyptus 33 (1953): 341-346.

Černý, J. A Coptic Etymological Dictionary. Cambridge: Cambridge U. P., 1976.

Chaîne, M. Le manuscrit de la version copte en dialecte sahidique des "Apophthegmata Patrum." Cairo: Imprimerie de l'Institut français d'archéologie orientale, 1960.

Çiçek, K. "Interpreters of the court in the Ottoman Empire as seen from the Sharia court records of Cyprus." Islamic Law and Society 9 (2002): 1-15.

Clarysse, W. "Greeks and Persians in a bilingual census list." In Acta Demotica: acts of the Fifth International Conference for Demotists, Pisa, 4th-8th September 1993, edited by E. Bresciani, 69-77. Pisa: Giardini, 1994.

Clarysse, W. and D. J. Thompson Counting the People in Hellenistic Egypt. Volume 1: population registers (P.Count); Volume 2: historical studies. Cambridge: Cambridge U. P., 2006.

Clarysse, W. and K. Vandorpe. Zenon, un homme d'affaires grec à l'ombre des pyramides. Louvain: Presses universitaires de Louvain, 1995.

Constantinidou, E. “The 'death' of East Sutherland Gaelic: death by women?” In Burton, Kushari Dyson and Ardener (1994), 111-127.

Crawford, D. J. "Garlic-growing and agricultural specialization in Graeco-Roman Egypt.” Chronique d'Égypte 48 (1973): 350-363.

Crum, W. E. A Coptic Dictionary. Oxford: Clarendon, 1939.

Dickey, E. “Review: ancient bilingualism.” JRS 93 (2003): 295-302.

Fewster, P. "Bilingualism in Roman Egypt." In Bilingualism in Ancient Society: language contact and the written text, edited by J. N. Adams, M. Janse and S. Swain, 220-245. Oxford: Oxford U. P., 2002.

Guy, J.-C. Les Apophtegmes des Pères: collection systématique. Vol. I Chapitres I-IX. Paris: Cerf, 1993.

Hanson, A. E. “Ancient illiteracy." In Literacy in the Roman World, edited by M. Beard, et al., 159-198. Ann Arbor: JRA, 1991.

Johnson, A. C. Roman Egypt to the Reign of Diocletian. Baltimore: Johns Hopkins U. P., 1936.

Johnson, D. W., editor. A Panegyric on Macarius, Bishop of Tkôw, Attributed to Dioscorus of Alexandria. Louvain: Secrétariat du CorpusSCO, 1980.

Kambitsis, S. Papyrus Graux III (P. Graux 30). Geneva: Droz, 1997.

Kelly, B. Petitions, Litigation, and Social Control in Roman Egypt. Oxford: Oxford U. P., 2011.

Kolnik, T. “Q. Atilius Primus - Interprex Centurio und Negotiator.” Acta Archaeologica Academiae Scientiarum Hungaricae 30 (1978): 61-75.

Kraemer, R. S., editor. Women's Religions in the Greco-Roman World: a sourcebook. Oxford: Oxford U. P., 2004.

Kytzler, B. "Fidus interpres: the theory and practice of translation in Classical Antiquity." Antichthon 23 (1989): 42-50.

La'da, C. Foreign Ethnics in Hellenistic Egypt. Leuven: Peeters, 2002a.

La'da, C. "Immigrant women in Hellenistic Egypt: the evidence of ethnic designations." In Le rôle et le statut de la femme en Égypte hellénistique, romaine et byzantine: actes du colloque 
international, Bruxelles-Leuven 27-29 novembre 1997, edited by H. Melaerts and L. Mooren, 167-192. Leuven: Peeters, 2002b.

Lewis, N. "The demise of the Demotic documents: when and why." Journal of Egyptian Archaeology 79 (1993): 276-281.

Mairs, R. "An early Roman application for lease of a date crop (P. Duk. inv. 85) and the 'six-choinix measure of the Hermeneus."” ZPE 172 (2010a): 183-191.

Mairs, R. “Egyptian 'inscriptions' and Greek 'graffiti' at El Kanais (Egyptian eastern desert)." In Ancient Graffiti in Context, edited by J. Baird and C. Taylor, 153-164. London: Routledge, 2010b.

Mairs, R. "Interpreters and translators in Hellenistic and Roman Egypt." In Actes du 26e Congrès international de papyrologie (Genève 2010), edited by P. Schubert, 457-462. Geneva: Droz, $2012 \mathrm{a}$.

Mairs, R. “'Interpreting' at Vindolanda." Britannia 43 (2012b): 1-12.

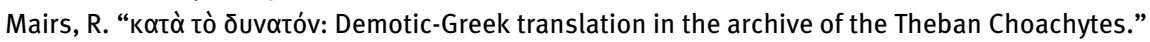
In Beyond Free Variation: scribal repertoires in Egypt from the Old Kingdom to the Early Islamic Period, edited by J. Cromwell and E. Grossman, 199-213. Oxford: Oxford U. P., 2018.

Mairs, R. "Interpretes, negotiatores and the Roman army: mobile professionals and their languages." In Migration, Mobility, and Language Contact in and around the Ancient Mediterranean, edited by P. James. Cambridge: Cambridge U. P., forthcoming.

Mairs, R. and C. J. Martin. "A bilingual 'sale' of liturgies from the archive of the Theban Choachytes: P. Berlin 5507, P. Berlin 3098 and P. Leiden 413.” Enchoria, Zeitschrift für Demotistik und Koptologie 31 (2008/2009): 22-67.

McDonald, M. "Women and linguistic innovation in Brittany." In Burton, Kushari Dyson and Ardener (1994), 85-110.

McElduff, S. Roman Theories of Translation. London: Routledge, 2013.

Mussies, G. "Egyptianisms in a late Ptolemaic document." In Antidoron Martino David Oblatum: Miscellanea Papyrologica (P.L. Bat. XVII), edited by E. Boswinkel, B.A. van Groningen and P. W. Pestman, 70-76. Leiden: Brill, 1968.

Papaconstantinou, A. editor. The Multilingual Experience in Egypt, from the Ptolemies to the 'Abbāsids. Farnham: Ashgate, 2010.

Parsons, P. The City of the Sharp-Nosed Fish: Greek lives in Roman Egypt. London: Weidenfeld and Nicolson, 2007.

Peremans, W. "Le bilinguisme dans les relations gréco-égyptiennes sous les Lagides." In Egypt and the Hellenistic World: proceedings of the International Colloquium Leuven 24-26 May 1982, edited by E. van't Dack, P. van Dessel and W. van Gucht, 253-280. Leuven: [Orientaliste], 1983a.

Peremans, W. "Les hermeneis dans l'Egypte gréco-romaine.” In Das römisch-byzantinische Ägypten, edited by G. Grimm, H. Heinen and E. Winter, 11-17. Mainz am Rhein: von Zabern, $1983 \mathrm{~b}$.

Peremans, W. “Notes sur les traductions de textes non littéraires sous les Lagides." Chronique d'Égypte 60 (1985); 248-262.

Pestman, P. W. A Guide to the Zenon Archive (P. L. Bat. 21). Leiden: Brill, 1981.

Pestman, P. W. "The competence of Greek and Egyptian tribunals according to the decree of 118 BC." Bulletin of the American Society of Papyrologists 22 (1985a); 265-269.

Pestman, P. W. "Registration of Demotic Contracts in Egypt: P. Par. 65; 2nd cent. B.C." In Satura Roberto Feenstra sexagesimum quintum annum aetatis complenti ab alumnis collegis ami- 
cis oblata, edited by J. Ankum, J. Spruit and F. Wubbe, 17-25. Fribourg: Éditions Universitaires, $1985 \mathrm{~b}$.

Pfeiffer, S. Das Dekret von Kanopos (238 v. Chr.): Kommentar und historische Auswertung eines dreisprachigen Synodaldekretes der ägyptischen Priester zu Ehren Ptolemaios' III. und seiner Familie. München: Saur, 2004.

Piller, I. and A. Pavlenko. "Bilingualism and gender." In The Handbook of Bilingualism, edited by T. K. Bhatia and W. C. Ritchie, 489-511. Oxford: Blackwell, 2004.

Porten, B., J. J. Farber, C. J. Martin, G. Vittmann, L. S. B. MacCoull and S. Clackson. The Elephantine Papyri in English: three millennia of cross-cultural continuity and change. Leiden: Brill, 1996.

Raschke, M. G. "The office of agoranomos in Ptolemaic and Roman Egypt." In Akten des XIII. Internationalen Papyrologenkongresses: Marburg/Lahn, 2-6. August 1971, edited by E. Kiessling and M.A. Rupprecht, 349-356. Munich: Beck, 1974.

Redford, D. B. “Egypt and western Asia in the Old Kingdom." Journal of the American Research Center in Egypt 23 (1986): 125-143.

Rochette, B. “Traducteurs et traductions dans l'Égypte gréco-romaine.” Chronique d'Égypte 69 (1994): 313-322.

Rochette, B. "Du grec au latin et du latin au grec: Les problèmes de la traduction dans l'antiquité gréco-latine." Latomus 54 (1995a), 245-261.

Rochette, B. “Qui est Apollonios? (UPZ II 227).” Aegyptus 75 (1995b), 61-67.

Rowlandson, J. Women and Society in Greek and Roman Egypt: a sourcebook. Cambridge: Cambridge U. P., 1998.

Rowlandson, J. "Gender and cultural identity in Roman Egypt." In Women's Influence on Classical Civilization, edited by F. McHardy and E. Marshall, 151-166. London: Routledge, 2004.

Salomon, R. "Epigraphic remains of Indian traders in Egypt.” Journal of the American Oriental Society 111 (1991): 731-736.

Schentuleit, M. "Die spätdemotische Hausverkaufsurkunde P. BM. 262: Ein bilingues Dokument aus Soknopaiu Nesos mit griechischen Übersetzungen." Enchoria, Zeitschrift für Demotistik und Koptologie 27 (2001): 127-154.

Schentuleit, M. "Satabus aus Soknopaiou Nesos: aus dem Leben eines Priesters am Beginn der römischen Kaiserzeit." Chronique d'Égypte 82 (2007): 101-125.

Sijpesteijn, P. J. “Four papyri from the Michigan Collection.” Tyche 9 (1994): 175-180.

Taubenschlag, R. "The interpreters in the Papyri." In Charisteria Thaddaeo Sinko: Quinquaginta abhinc annos amplissimis in philosophia honoribus ornato ab amicis collegis discipulis oblata, edited by K. F. Kumaniecki, 361-363. Warsaw: Sumptibus Societatis Philologae Polonorum, 1951.

Thomas, J. and A. Constantinides Hero, editors. Byzantine Monastic Foundation Documents: $a$ complete translation of the surviving founders' typika and testaments. Washington: Dumbarton Oaks Research Library and Collection, 2000.

Tomber, R. "Troglodytes and trogodytes: exploring interaction on the Red Sea during the Roman period." In People of the Red Sea: proceedings of the Red Sea Project 2, edited by J.

C. M. Starkey, 41-49. Oxford: BAR, 2005.

Torallas Tovar, S. “Linguistic identity in Graeco-Roman Egypt.” In Papaconstantinou (2010), 17-43.

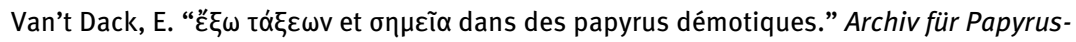
forschung und verwandte Gebiete 19 (1969): 155-165. 
Vandorpe, K. “Apollonia, a businesswoman in a multicultural society (Pathyris, 2nd-1st centuries $\mathrm{BC})$." In Le rôle et le statut de la femme en Égypte hellénistique, romaine et byzantine: actes du colloque international, Bruxelles-Leuven 27-29 Novembre 1997, edited by H. Melaerts and L. Mooren, 325-336. Leuven: Peeters, 2002.

Vandorpe, K. "Persian soldiers and Persians of the Epigone. Social mobility of soldiers-herdsmen in Upper Egypt." Archiv für Papyrusforschung und verwandte Gebiete 54 (2008): 87-108.

Ward, B. The Sayings of the Desert Fathers: the alphabetical collection. London: Mowbrays, 1975. Wente, E. F. Letters from Ancient Egypt. Atlanta: Scholars, 1990.

West, S. “P. Ryl. 62: the power of astrology." ZPE 14 (1974): 227-228.

Westermann, W. L., C. W. Keyes and H. Liebesny, editors. Zenon Papyri: business papers of the third century BC. Dealing with Palestine and Egypt. Vol. II. New York: Columbia U. P., 1940.

Wiotte-Franz, C. Hermeneus und Interpres: zum Dolmetscherwesen in der Antike. Saarbrücken: Saarbrücker Druckerei und Verlag, 2001.

Youtie, H. C. “AGRAMMATOS: an aspect of Greek society in Egypt.” HSCPh 75 (1971): 161-176.

Youtie, H. C. “ن்пор $\alpha \varphi \varepsilon u ́ c:$ the social impact of illiteracy in Graeco-Roman Egypt.” ZPE 17 (1975): 201-221. 